[Pre-print - authors' accepted manuscript version. Please cite as the published version: Chilvers, J., Lorenzoni, I., Terry, G., Buckley, P., Pinnegar, J.K. \& Gelcich, S. (2014) 'Public engagement with marine climate change issues: (Re)framings, understandings and responses', Global Environmental Change 29: 165-179. Available at: http://dx.doi.org/10.1016/j.gloenvcha.2014.09.006]

\title{
Public engagement with marine climate change issues: (Re)framings, understandings and responses
}

${ }^{a^{*} J a s o n}$ Chilvers, ${ }^{a}$ Irene Lorenzoni, ${ }^{b}$ Geraldine Terry, ${ }^{c}$ Paul Buckley, ${ }^{c}$ John. K. Pinnegar and ${ }^{d}$ Stefan Gelcich.

\begin{abstract}
Climate change impacts on marine environments have been somewhat neglected in climate change research, particularly with regard to their social dimensions and implications. This paper contributes to addressing this gap through presenting a UK focused mixed-method study of how publics frame, understand and respond to marine climate change-related issues. It draws on data from a large national survey of UK publics ( $\mathrm{N}=1,001)$, undertaken in January 2011 as part of a wider European survey, in conjunction with in-depth qualitative insights from a citizens' panel with participants from the East Anglia region, UK. This reveals that discrete marine climate change impacts, as often framed in technical or institutional terms, were not the most immediate or significant issues for most respondents. Study participants tended to view these climate impacts 'in context', in situated ways, and as entangled with other issues relating to marine environments and their everyday lives. Whilst making connections with scientific knowledge on the subject, public understandings of marine climate impacts were mainly shaped by personal experience, the visibility and proximity of impacts, sense of personal risk and moral or equity-based arguments. In terms of responses, study participants prioritised climate change mitigation measures over adaptation, even in high-risk areas. We consider the implications of these insights for research and practices of public engagement on marine climate impacts specifically, and climate change more generally.
\end{abstract}

Keywords: Marine climate change impacts; Public understandings; Public engagement; Mixedmethodology; (Re)framing; Climate change as a public issue.

\footnotetext{
${ }^{a}$ Science, Society and Sustainability (3S) Research Group, School of Environmental Sciences, University of East Anglia, Norwich, UK.

${ }^{\mathrm{b}}$ School of International Development, University of East Anglia, Norwich, UK.

${ }^{\mathrm{c}}$ Centre for Environment, Fisheries and Aquaculture Science (CEFAS), Pakefield Road, Lowestoft, Suffolk, UK.

${ }^{\mathrm{d}}$ Center of Applied Ecology and Sustainability (CAPES) \& Laboratorio Internacional en Cambio Global (LINCGlobal), Facultad de Ciencias Biologicas, Pontificia Universidad Catolica de Chile, Santiago, Chile.

${ }^{*}$ Corresponding author: Dr Jason Chilvers: Science, Society and Sustainability (3S) Research Group, School of Environmental Sciences, University of East Anglia, Norwich NR4 7TJ, UK. Tel: +44 (0)1603 593130

Email: jason.chilvers@uea.ac.uk
} 
[Pre-print - authors' accepted manuscript version. Please cite as the published version: Chilvers, J., Lorenzoni, I., Terry, G., Buckley, P., Pinnegar, J.K. \& Gelcich, S. (2014) 'Public engagement with marine climate change issues: (Re)framings, understandings and responses', Global Environmental Change 29: 165-179. Available at: http://dx.doi.org/10.1016/j.gloenvcha.2014.09.006]

\section{Introduction}

Climate change has emerged as the dominant global environmental change issue of the past decade driven by scientific observations and model outputs, projections of severe socio-economic impacts, coupled with widespread public and political concern. Addressing both the causes and effects of climate change is proving to be challenging, as the climate change negotiations in Copenhagen (December 2009) and Durban (December 2011) testified; however, considerable global attention and scientific effort is currently channelled towards the climate change conference in Paris in 2015. Research on climate change in relation to marine ecosystems has been relatively limited. For example, the Fourth Assessment of the Intergovernmental Panel on Climate Change noted 28,586 significant biological changes in terrestrial systems but only 85 in marine and freshwater systems (IPCC, 2007a,b; Richardson and Poloczanska, 2008). As of late 2011, of 84,723 scientific papers published on climate change, only 6,624 (7.8\%) dealt with marine climate change despite the fact that oceans represent $70 \%$ of the Earth's surface (Heip, 2011). Research in this area is progressing, resulting partly in greater focus on marine climate impacts in the IPCC's recent Fifth Assessment Report, which highlighted the "risk of loss of marine and coastal ecosystems, biodiversity, and the ecosystem goods, functions, and services" (IPCC, 2014: 12).

Not only are marine and coastal environments crucial in mediating changes in the Earth's climatic system (Le Quéré et al., 2009), scientific evidence shows they also stand to bear severe marine climate change impacts. These range from natural and physical ocean changes in sea-level, temperature, circulation, acidification, and species distribution; coastal erosion and flooding; through to impacts on fisheries, tourism and transport (see Heip et al., 2011; Philippart et al., 2011). Research indicates that such impacts could lead to major socio-economic changes. For instance, fisheries are projected to lose yields in low latitude countries and possibly benefit in higher latitudes (Cheung et al. 2010). Costs of a $44 \mathrm{~cm}$ sea level rise across Europe have been estimated at $€ 12$ billion per year in 2100 (Hinkel et al. 2010), with changes in sea level being associated with inundation of land and population displacement (Tol, 2007).

In relative terms, the lesser attention to marine climate change impacts in natural scientific research is mirrored in research on the social dimensions of climate change. While there is now a substantial body of research on the ways in which publics understand and perceive climate change more generally (e.g. Lorenzoni et al., 2006; Whitmarsh, 2009; Brechin and Bhandari, 2014), how this is mediated through cultural values and worldviews, media discourses and trust in science and institutions (Poortinga and Pidgeon, 2003; Carvalho and Burgess, 2005; Lorenzoni et al., 2006; Wolf 
[Pre-print - authors' accepted manuscript version. Please cite as the published version: Chilvers, J., Lorenzoni, I., Terry, G., Buckley, P., Pinnegar, J.K. \& Gelcich, S. (2014) 'Public engagement with marine climate change issues: (Re)framings, understandings and responses', Global Environmental Change 29: 165-179. Available at: http://dx.doi.org/10.1016/j.gloenvcha.2014.09.006]

and Moser, 2011; Corner et al, 2014) and the transformation of individual behaviours and practices in mitigating climate change (e.g. Lorenzoni et al., 2007; Shove, 2010; Shwom and Lorenzen, 2012), insights in relation to marine climate change issues are less plentiful. Most human populations are indirectly, if not directly, at risk from marine climate change impacts, which stand to intensify through time and demand robust adaptation responses alongside attempts to build the resilience of natural and social systems (Adger et al., 2009). Such responses will in part depend on a deeper understanding of how publics perceive, engage with and respond to marine climate change issues in their own terms if they are to be sustainable (cf. Irwin and Wynne, 1996).

To date, much research into public perceptions of, and responses to, marine climate change impacts has focussed on single hazards or impacts (although see Harvatt et al., 2011) with emphasis on exploring immediate or tangible issues of sea-level rise (e.g. Myatt-Bell et al., 2002; Van Koningsveld et al., 2008), associated coastal flooding (e.g. Zsamboky et al., 2011) and coastal erosion (e.g. Dolan and Walker, 2006). More recent work has begun to cover the diversity of marine climate change impacts outlined above in both developed and developing country contexts. Carlton and Jacobson (2013) explored perceptions of less visible impacts of climate change, finding that (in line with other literature) climate change risks are multiple and perceived differently by individuals, who understand these through experiential processing. Studies have also explored perceptions of coastal hazards in relation to climate change and livelihoods in the global South (e.g. Bunce et al., 2010; Linnekamp et al., 2011; Combest-Friedman et al., 2012).

In order to address these gaps in global environmental change research this paper reports on a study that is novel in that it explores public engagement across multiple marine climate impacts and includes the first large-scale public survey on the subject. This wider study sought to better understand how publics perceive, engage with and respond to marine climate change issues across Europe (also see Gelcich et al. in press). In this paper we focus on findings from the UK, which was the sole country of the European study where in-depth qualitative research was conducted in addition to the quantitative survey (see the Methodology section below). The paper thus aims to offer new insights into how publics frame, understand and respond to marine climate change-related issues through a UK focused mixed-method analysis.

The UK is an important cultural-political setting in which to study how publics relate to marine climate change issues. The UK operates within a strong legislative framework aiming to address the causes and impacts of climate change, which builds upon a legacy of historical and more recent policy 
[Pre-print - authors' accepted manuscript version. Please cite as the published version: Chilvers, J., Lorenzoni, I., Terry, G., Buckley, P., Pinnegar, J.K. \& Gelcich, S. (2014) 'Public engagement with marine climate change issues: (Re)framings, understandings and responses', Global Environmental Change 29: 165-179. Available at: http://dx.doi.org/10.1016/j.gloenvcha.2014.09.006]

initiatives. Since 2008, the UK Climate Change Act provides a national framework for achieving long-term mitigation ( $80 \%$ reduction of national greenhouse gas emissions by 2050 ) and fostering adaptation. The nation's first Climate Change Risk Assessment (DEFRA, 2012) indicates that:

"around $3000 \mathrm{~km}(17 \%)$ of the UK coast is currently eroding. Climate change may lead to a $100 \%$ to $400 \%$ increase in erosion rate, compared with the current rate. While still affecting only a very small proportion of the UK's total land area, locally this might have significant implications for communities and habitats".

Indeed the UK has a long legacy of dealing with the well-recognised threat of coastal erosion and flooding. For over 50 years investment has focused on engineering options often resulting in hard defences protecting the coastline, with allowances for climate change applied since the 1990s. The overall approach to flood risk management over the past decade has placed more emphasis on reducing financial investment in flood defences, including flood risk considerations in planning decisions and fostering social resilience to change. However, stakeholder interests continue to favour structural approaches to flood risk protection (Harries and Penning-Rowsell, 2011). The UK public has generally reported high awareness and concern about climate change, although scepticism has been growing since about 2006 (e.g. Spence et al., 2010a). In this population, experience of flooding has been shown in some studies to be directly related to willingness to take personal action (Harvatt et al., 2011) and especially to mitigate through energy reduction (Spence et al., 2010a). Flooding experience has been found to correlate with higher concern about climate change and belief in the efficacy of individual behaviours (Spence et al., 2011).

The next section reviews existing research into how the public understand and engage with marine climate change issues. We then present the main findings and three distinctive contributions of our UK survey coupled with in-depth qualitative research. First, we analyse how UK public participants defined and framed marine climate change issues in their own terms. Second, we explore findings on public understandings and knowledges with respect to marine climate change. Third we outline public views on responses with respect to mitigation and adaptation. In the final discussion and conclusion section, we draw together key findings from across these sections, reflect on them in relation to the existing literature, and consider implications for future research and practices of public engagement with marine climate change issues. 
[Pre-print - authors' accepted manuscript version. Please cite as the published version: Chilvers, J., Lorenzoni, I., Terry, G., Buckley, P., Pinnegar, J.K. \& Gelcich, S. (2014) 'Public engagement with marine climate change issues: (Re)framings, understandings and responses', Global Environmental Change 29: 165-179. Available at: http://dx.doi.org/10.1016/j.gloenvcha.2014.09.006]

\section{Background}

Few studies have directly addressed how publics understand and engage with marine climate change issues, although the literature has recently expanded in this area. In this section we briefly review these specific studies and gain further insight into these dynamics from work on perceptions of climate change and how publics relate to marine environments more generally. We also consider diverse forms of public participation and engagement on these issues. We define 'public engagement' broadly in terms of the various ways in which people relate to climate change-related issues in general and marine climate change in particular. This combines definitions of public engagement as an individual's state of knowledge, values and behaviour relating to climate change (e.g. Lorenzoni et al. 2007), with those that emphasise collective forms of public engagement in policy making, science, forms of activism, and social innovation (e.g. Kasemir et al., 2003; Felt and Wynne, 2007; Wynne, 2007; Chilvers, 2008; Callon et al 2009). For the purpose of this paper we use the term 'publics' deliberately to acknowledge the diversity and plurality of publics as opposed to more traditional conceptions of 'the public' as a homogeneous entity (cf. Irwin and Wynne, 1996).

Among the limited number of studies exploring public engagement with marine climate change impacts, most focus rather narrowly on personal and social risk perceptions of particular impacts. Small scale surveys in the UK, USA and Sweden (Lorenzoni et al., 2006, Sundblad et al., 2007) and research with vulnerable communities in the UK (Bickerstaff et al., 2006) indicate that sea level rise, coastal flooding and erosion are associated with climate change by the public at large, but these have limited personal salience. Similarly, the limited evidence on engagement with less publicly-visible impacts, such as ocean acidification, suggests that these are psychologically distant (personally irrelevant, emotionally unengaging, e.g. O'Neill and Hulme, 2009). Evidence with regards to the influence of direct experience of flooding on engagement with climate change is contradictory: some studies suggest it enhances the connection with, and awareness of, climate change risks (see Harvatt et al 2011; Spence et al. 2011; Zsamboky et al 2011), whilst other empirical work does not support this relationship (e.g. Whitmarsh, 2008). More recently, a survey of Irish citizens' attitudes to marine environments suggested that their views on the most significant threats do not for the most part correspond with those of expert or scientific communities (Hyne et al., 2014).

The small number of studies which consider public reactions to climate change mitigation initiatives in or under the sea offer useful insights into understanding how changes to marine environments are perceived. Exploration of perceptions of wind and tidal energies in relation to aesthetic values and place (Haggett, 2008; McLachlan, 2009; Gee, 2010; Devine-Wright and Howes, 2010; DevineWright, 2011) and Shackley et al.'s (2005) study on public reactions to carbon capture and storage 
[Pre-print - authors' accepted manuscript version. Please cite as the published version: Chilvers, J., Lorenzoni, I., Terry, G., Buckley, P., Pinnegar, J.K. \& Gelcich, S. (2014) 'Public engagement with marine climate change issues: (Re)framings, understandings and responses', Global Environmental Change 29: 165-179. Available at: http://dx.doi.org/10.1016/j.gloenvcha.2014.09.006]

illustrate strong personal connections to marine and coastal environments, affected by sense of aesthetics, practical considerations (livelihoods, impact on marine wildlife, national energy production), proximity and the 'nature' of the environment (e.g. as a source of life to be respected). Some individuals view marine environments as areas to be protected from human 'pollution' for moral as well as practical reasons, for example for the various services they provide (see also Fletcher et al. 2009, as well as Mee et al.'s (2008) re-analysis of Eurobarometer surveys on citizens' concerns in relation to marine environments).

Among the wide body of literature concerning public engagement with climate change, findings consistently indicate - as elucidated here using the example of a 2009 European survey - a generally informed European public on the causes (56\% of respondents) and consequences (56\%) of climate change and ways of addressing it (52\%), although the proportion of citizens that feel poorly informed about the subject remains significant, at $9 \%$ (data reported by the European Commission and European Parliament, 2009). Furthermore, in this survey most Europeans declared high concern about climate change, with $67 \%$ viewing it as a 'very serious issue'. Smaller surveys within individual EU nations also show high levels of concern (e.g. Paeth and Otto, 2009; Spence et al., 2010b; Whitmarsh, 2011). In the UK a decline in public concern since 2006 has been documented (see Spence et al., 2010a), although its attribution remains difficult to define. On the other hand, while climate change is viewed as an important issue it is generally perceived as less important than certain other global problems. For the most part individuals in developed nations perceive climate change as a serious but remote risk, although examination by Spence and colleagues (2012) reveals that among the British population this is more nuanced. Respondents in their study perceived climate change as both psychologically distant and close, in space and time, which may be influenced by the perceived significance or magnitude of impact (suggesting a relationship between concern about climate change and psychological distance). Risk perceptions are an important but limited contributor to engagement. This is dependent on individuals' sense of being capable of responding (i.e. perceived self-efficacy, e.g. Grothmann and Patt 2005; Lorenzoni et al., 2007; Harvatt et al., 2011) and trust in institutions (Poortinga and Pidgeon 2003; Van Koningsveld et al., 2008; Malka et al., 2009).

Processes encouraging public discussion on climate change impacts have been employed in attempts to raise awareness of the risks and the range of alternative responses. For example, some researchers advocate increased use of participatory deliberation in order to foster people's sense of self-efficacy (Brody et al., 2008) or move beyond the entrenched positions associated with different values and worldviews (Verweij et al., 2006; Shwom et al., 2010; Whitmarsh, 2011). Deliberative public 
[Pre-print - authors' accepted manuscript version. Please cite as the published version: Chilvers, J., Lorenzoni, I., Terry, G., Buckley, P., Pinnegar, J.K. \& Gelcich, S. (2014) 'Public engagement with marine climate change issues: (Re)framings, understandings and responses', Global Environmental Change 29: 165-179. Available at: http://dx.doi.org/10.1016/j.gloenvcha.2014.09.006]

engagement processes can include invited participatory assessments and 'citizen science' initiatives which provide spaces to which members of the public and stakeholders are invited, sometimes being specially selected for the purpose (e.g. ATLANTIS project on sea level rise, Lonsdale et al., 2008; Bunce et al., 2010 on perceptions of climate change on African coasts), through to 'uninvited spaces' (Wynne, 2007; Chilvers and Evans, 2009) in which members of the public respond to marine environmental issues in diverse ways either on their own initiative or through civil society organisations. Recent campaigns suggest that there is substantial public concern for marine environmental issues beyond a narrow focus on risk to humans, as seen for example through Greenpeace's Defending Our Oceans campaign (e.g. Greenpeace, 2010) and British celebrity chef Hugh Fearnley-Whittingstall's Fish Fight campaign against the EU's Common Fisheries Policy (which over 870,000 people across 195 countries worldwide signed the petition for - see www.fishfight.net). Such instances of public advocacy indicate considerable interest among individuals to engage with marine environmental and climate change issues on their own terms. There is likely to be a wide diversity of legitimate stakeholder perspectives and instances of public engagement on coastal and marine issues that need to be given a voice in shaping future actions and developing a vision of a 'sea interest' (Ritchie and Ellis, 2010; Van Koningsveld et al., 2008).

\section{Methodology}

A mixed-method research design was employed in the current study. It integrated (i) a large national survey, which gained insights into what a nationally representative sample of 1,001 UK members of the public think about marine climate change issues, with (ii) in-depth qualitative research in the form of a deliberative workshop which involved a select group of 20 citizens from the UK East Anglian region exploring the underlying factors shaping public understandings and responses. The two methods explored similar themes and the resulting data were analysed in conjunction. The survey research provides data on what a wider population of UK public respondents think about marine climate change issues but - in keeping with the limits of questionnaire-based approaches - gives limited insight into why this is the case. The purpose of the in-depth qualitative research, undertaken after the large-scale survey, was to explore public views on these why questions in more depth, to reveal the underlying reasonings, factors and concerns that shape public understandings and responses to marine climate change issues. Such triangulation of distinct-but-linked methods can enhance the richness and robustness of the analytical findings presented (Jick, 1979; Bryman, 2004). It is important to note, however, that the in-depth qualitative research did not seek to be 'representative' 
[Pre-print - authors' accepted manuscript version. Please cite as the published version: Chilvers, J., Lorenzoni, I., Terry, G., Buckley, P., Pinnegar, J.K. \& Gelcich, S. (2014) 'Public engagement with marine climate change issues: (Re)framings, understandings and responses', Global Environmental Change 29: 165-179. Available at: http://dx.doi.org/10.1016/j.gloenvcha.2014.09.006]

across UK publics, but rather reveal deeper insights from public participants in a region of the UK, in order to complement, deepen and further the interpretation of survey responses.

\subsection{Public survey}

The survey was conceived and designed by the research team drawing from an extensive literature review, and informed by key questions in the wider project (see below). It comprised a questionnaire structured into three sections. The first section sought to explore public framings of marine climate change impacts set in the wider context of marine environmental issues and climate change more generally. The second section explored public knowledge of marine climate impacts, information sources, and questions of trust in societal actors. The third section gained respondents' views on possible responses to these impacts at the levels of individual behaviour change and policy-making at multiple scales (further details of specific survey questions asked are given when presenting the results below in Section 4; a copy of the full questionnaire is available from the authors). The questionnaire was designed to include a mix of multiple choice questions, Likert scale responses, and free elicitations of word associations (e.g. as used by Lorenzoni et al., 2006). The latter were employed at the beginning of the survey to allow respondents to define relevant issues in their own terms and as they came to mind (immediacy and availability), with no ranking required. This method was designed to minimise framing effects by enabling personal, spontaneous and relatively unfiltered responses, providing access to subjective associations and meanings, thus offering some insight into how publics frame marine climate change issues in their own terms (this method has been used previously in some large scale studies, see Lorenzoni et al. 2006, Sherry-Brennan et al., 2010). In this paper by framing we mean how the issue of climate change is defined, presented, and the meanings associated with it by any scientific, policy or social actor - although our specific focus here is on framings by publics. In regard to the concept of framing, we draw upon Nisbet's (2009) definition.

The UK survey formed part of a wider European survey on marine climate change impacts undertaken by the research team as part of an EU-funded project (CLAMER). TNS-BMRB, a large social research company with good UK and European-wide coverage and experience, was commissioned to conduct the survey in January 2011. The survey was administered online. Survey respondents were recruited from TNS-BMRB's UK online panel of 361,798 people, which is built to be representative of the national population (including in relation to categories of gender, age, region, education, and social grade) and is continuously updated. The UK internet penetration rate at the time of study was $82.5 \%$. A proportion of the panel respondents (adults, 18 years and over) were invited to participate in the online survey via invitation emails. Invitations were repeated until hard quotas were met for age, 
[Pre-print - authors' accepted manuscript version. Please cite as the published version: Chilvers, J., Lorenzoni, I., Terry, G., Buckley, P., Pinnegar, J.K. \& Gelcich, S. (2014) 'Public engagement with marine climate change issues: (Re)framings, understandings and responses', Global Environmental Change 29: 165-179. Available at: http://dx.doi.org/10.1016/j.gloenvcha.2014.09.006]

gender, geographical region and social grade to ensure a statistically representative sample based on these socio-demographic characteristics (see Table 1). The online methodology did not allow a definitive response rate to be calculated, partly because the system did not allow responses after quotas had been met and because a real time index of all e-mail addresses that make up the online panel was not available. The total UK response sample size was 1001 (850 drawn from the general population with a 151 oversample of adults living in coastal areas). Of these 1001 respondents, small proportions indicated they lived in the East of England ( $\mathrm{N}=78)$ and 'coastal areas of East [England]' (Eastern coast, $\mathrm{N}=43$ ). The introductory letter sent to members of the online panel did not explicitly mention the survey topic to minimise prior framing effects, due to the importance of exploring open public framings at the beginning of the questionnaire. All respondents filled out the 20-minute questionnaire online via a dedicated URL link that they were permitted to access only once.

\begin{tabular}{|c|c|c|c|}
\hline \multicolumn{3}{|c|}{ Survey Sample } & \multirow{2}{*}{$\begin{array}{c}\text { UK } 2001 \text { Census } \\
\text { Percentage }\end{array}$} \\
\hline Che & racteristic & Percentage of total & \\
\hline Gender & \begin{tabular}{|l|} 
Male \\
Female
\end{tabular} & $\begin{array}{l}48 \\
52\end{array}$ & $\begin{array}{l}48.4 \\
51.5\end{array}$ \\
\hline Age & \begin{tabular}{|l|}
$18-24$ \\
$25-34$ \\
$35-44$ \\
$45-54$ \\
$55-64$ \\
$65+$
\end{tabular} & $\begin{array}{l}11 \\
19 \\
19 \\
16 \\
14 \\
21\end{array}$ & $\begin{array}{c}6.2(\text { aged } 20-24) \\
29.2(\text { aged } 25-44) \\
\\
18.5(\text { aged } 45-59) \\
4.8(\text { aged } 60-64) \\
3.8\end{array}$ \\
\hline Location & Coastal & 34 & - \\
\hline $\begin{array}{l}\text { Class (based on } \\
\text { occupation) }\end{array}$ & $\begin{array}{l}\text { ABC1 (NET) } \\
\text { C2DE (NET) }\end{array}$ & $\begin{array}{l}58 \\
42\end{array}$ & \\
\hline Employment status & \begin{tabular}{|l|} 
Full-Time Paid Work \\
$(30+$ Hours Per Week $)$
\end{tabular} & 38 & 40 \\
\hline $\begin{array}{l}\text { Age when finished } \\
\text { full time education }\end{array}$ & $\begin{array}{l}16 \text { and under } \\
17-18 \\
19-22 \\
23 \text { and over } \\
\text { Still in education } \\
\text { Refused to answer }\end{array}$ & $\begin{array}{c}32 \\
25 \\
23 \\
14 \\
5 \\
1\end{array}$ & \\
\hline
\end{tabular}

Table 1. Characteristics of the UK survey sample $(\mathrm{N}=1001)$ given in percentages (compared to that of the UK 2001 census population). 
[Pre-print - authors' accepted manuscript version. Please cite as the published version: Chilvers, J., Lorenzoni, I., Terry, G., Buckley, P., Pinnegar, J.K. \& Gelcich, S. (2014) 'Public engagement with marine climate change issues: (Re)framings, understandings and responses', Global Environmental Change 29: 165-179. Available at: http://dx.doi.org/10.1016/j.gloenvcha.2014.09.006]

Survey data were subject to descriptive and inferential analysis undertaken by the research team, which also included extensive coding of open responses from the beginning of the questionnaire into key analytical categories drawn from the data itself rather than pre-defined themes. Coding of open elicitations followed a set coding protocol (where codes were formed for regular verbatim responses mentioned by over $3 \%$ of the sample), was conducted by one of the research team, and checked for accuracy and consistency by two other members of the team. The analysis presented in this article seeks to explore location in relation to individuals' framings, understandings and responses to marine climate change impacts. Survey responses are related to socio-demographic variations in other outputs by the authors.

\subsection{In-depth qualitative research}

The in-depth qualitative part of the study brought together 20 members of the public with several climate change and marine environmental specialists in a day-long deliberative workshop held in West Runton situated on the North Norfolk coastline (in the county of Norfolk, within the Eastern region of the United Kingdom) on 25th June 2011. This in-depth approach served to complement, extend and further explain the survey findings. The rationale for this was twofold. First, the deliberative workshop provided opportunities for respondents to engage in a deeper, more interactive, and openly framed discussion which provided additional data on 'why' questions - for example in exploring the reasons underpinning forms of public understanding and response - thus aiding the interpretation of large-scale patterns and insights emerging from the more quantitative online survey (cf. Lorenzoni, 2006; Wolf and Moser, 2011). Second, the participatory nature of the workshop gave participants time and space to learn about and reflect on the issues in question in interaction with experts and fellow citizens (Webler et al., 1995; Chilvers, 2008), thus producing more informed and considered views on marine climate impacts than was afforded within the constraints of the largescale online questionnaire.

Half of the workshop participants $(\mathrm{N}=10)$ were recruited from the North Norfolk coastal area and half $(\mathrm{N}=10)$ from Norwich (a city of c.140,100 inhabitants situated c.30 kilometres inland from the North Norfolk coast), selected to reflect key socio-demographic characteristics of both areas according to the most recent census records (see Table 2 for full details). Workshop participants were recruited through adverts in local communities and through completing a screening questionnaire; this enabled meeting sample quotas for socio-demographics of the two areas. Participants were invited to be involved in a discussion of environmental issues (not climate change per se) and received a small honorarium of $£ 50$ in addition to travel costs for participating. 
[Pre-print - authors' accepted manuscript version. Please cite as the published version: Chilvers, J., Lorenzoni, I., Terry, G., Buckley, P., Pinnegar, J.K. \& Gelcich, S. (2014) 'Public engagement with marine climate change issues: (Re)framings, understandings and responses', Global Environmental Change 29: 165-179. Available at: http://dx.doi.org/10.1016/j.gloenvcha.2014.09.006]

\begin{tabular}{|c|c|c|c|c|c|}
\hline \multicolumn{6}{|c|}{ Norwich public participants $(\mathrm{N}=10)$} \\
\hline & & \multicolumn{4}{|c|}{ Age-group } \\
\hline & & $\begin{array}{l}18-24 \\
(13 \%)\end{array}$ & $\begin{array}{l}25-44 \\
(29 \%)\end{array}$ & $\begin{array}{l}45-64 \\
(21 \%)\end{array}$ & $\begin{array}{c}65+ \\
(17 \%)\end{array}$ \\
\hline \multirow{2}{*}{$\begin{array}{l}\text { Socio- } \\
\text { economic } \\
\text { classification }\end{array}$} & $\begin{array}{l}\text { NS-SEC 1-3 } \\
\text { or student } \\
(43 \%)\end{array}$ & $\operatorname{Jed}(\mathrm{M})$ & $\begin{array}{c}\text { Carrie (F) } \\
\text { Joseph (M) }\end{array}$ & Donald (M) & \\
\hline & $\begin{array}{l}\text { NS-SEC } 4-8 \text { or } \\
\text { unclassified } \\
(57 \%)\end{array}$ & Siobhan $(\mathrm{F})$ & $\begin{array}{l}\text { Rebecca (F) } \\
\text { Michael (M) }\end{array}$ & $\begin{array}{l}\text { Tanya (F) } \\
\text { Jessica (F) }\end{array}$ & $\operatorname{Reg}(\mathrm{M})$ \\
\hline \multicolumn{6}{|c|}{ North Norfolk public participants $(\mathrm{N}=10)$} \\
\hline & & \multicolumn{4}{|c|}{ Age-group } \\
\hline & & $\begin{array}{c}18-24 \\
(6 \%)\end{array}$ & $\begin{array}{l}25-44 \\
(22 \%)\end{array}$ & $\begin{array}{l}45-64 \\
(28 \%)\end{array}$ & $\begin{array}{c}65+ \\
(25 \%)\end{array}$ \\
\hline \multirow{2}{*}{$\begin{array}{l}\text { Socio- } \\
\text { economic } \\
\text { classification }\end{array}$} & $\begin{array}{l}\text { NS-SEC 1-3 } \\
\text { or student } \\
(31 \%)\end{array}$ & & $\begin{array}{l}\text { Simone (F) } \\
\text { Adrian (M) }\end{array}$ & Ralph (M) & \\
\hline & $\begin{array}{l}\text { NS-SEC } 4-8 \text { or } \\
\text { unclassified } \\
(69 \%)\end{array}$ & Zahra (F) & & $\begin{array}{c}\text { Marion (F) } \\
\text { Derek (M) } \\
\text { Bill (M) }\end{array}$ & $\begin{array}{c}\text { Barbara (F) } \\
\text { Ivy (F) } \\
\text { Daniel (M) }\end{array}$ \\
\hline
\end{tabular}

Table 2. A summary of the workshop participants and their key socio-demographic characteristics in terms of age, gender and socio-economic status ( $\mathrm{F}=$ female; $\mathrm{M}=$ Male; NS-SEC = National Statistics Socio-economic classification; NS-SEC 1-3 = Chief household earner in higher to lower professional / technical occupations; NS-SEC 4-8 = lower supervisory / routine occupations or unemployed).

Numbers given in percentages (\%) represent the actual proportion of the local population in each age or socio-economic category based on UK Office of National Statistics 2001 census data. Participants' real names have been replaced with pseudonyms.

The workshop was structured into three main sessions and adopted a hybrid methodology drawing on different qualitative participatory methods in each.

- The first session drew on focus group/in-depth group methods (Burgess et al., 1998) in allowing participants to openly explore framings of climate change and marine environments in their own terms. The interview protocol asked participants to discuss their understandings and engagement first with marine environments in general before moving on to more specific considerations of climate impacts. Here participants drew on their own experiences and relations to the topic prior to receiving any additional information.

- In the second session public participants engaged with information and expertise on marine climate impacts in a highly interactive process inspired by the Deliberative Mapping approach 
[Pre-print - authors' accepted manuscript version. Please cite as the published version: Chilvers, J., Lorenzoni, I., Terry, G., Buckley, P., Pinnegar, J.K. \& Gelcich, S. (2014) 'Public engagement with marine climate change issues: (Re)framings, understandings and responses', Global Environmental Change 29: 165-179. Available at: http://dx.doi.org/10.1016/j.gloenvcha.2014.09.006]

(Burgess et al., 2007; Chilvers and Burgess, 2008). Participants interacted with expert and scientifically-defined perspectives on marine climate impacts - both through interacting with experts and through studying poster displays each of which provided information on: coastal flooding, extreme weather, coastal erosion, ocean acidification, sea level rise, changes in ocean currents, melting sea ice, rising sea temperatures, and changes in marine species distributions. As part of this session participants also took part in a beach walk led by the expert representatives, allowing direct connection with the issues involved in a way not usually afforded in deliberative processes that emphasise public talk (cf. Carolan, 2007). After considering relevant information and expertise participants reflected on this and expressed areas of concern in relation to different marine climate change impacts.

- A final session considered responses and policy priorities, drawing in part on participatory appraisal techniques (Chambers, 1994) to give participants an active role in making judgements on the priorities for action in responding to marine climate change issues, both in terms of their own individual actions and those of science and policy institutions.

All workshop discussions were audio recorded and fully transcribed. Transcripts were then subject to qualitative coding analysis according to established methodological protocols (Silverman, 1993) to develop key analytical themes from across the qualitative dataset and explore areas of consensus and difference between participant perspectives within these themes, as presented below. Codes were developed from prior sensitising concepts identified in the literature review and from close reading of the data itself, around the top level themes of: the meanings of marine climate change issues as matters of public concern, public knowledge and understanding, and public responses and responsibilities.

\section{Public engagement with marine climate change issues}

In this section the large-scale survey and in-depth qualitative data are analysed in conjunction and directly compared in relation to three key themes each of which are presented in turn, namely: (i) the framing of marine climate change issues by study participants in their own terms; (ii) the nature of public knowledge and understanding of marine climate impacts; and (iii) public views on the responses of various actors (including themselves) to the threats posed. For each of these three themes, analysis of the survey data is presented first followed by qualitative findings. Where appropriate we show survey results for the whole of the UK ( $=1001)$ alongside subsamples for the East of England and the Eastern coast to aid direct comparisons between the wider UK dataset and the region and locality where the citizens' panel took place. 
[Pre-print - authors' accepted manuscript version. Please cite as the published version: Chilvers, J., Lorenzoni, I., Terry, G., Buckley, P., Pinnegar, J.K. \& Gelcich, S. (2014) 'Public engagement with marine climate change issues: (Re)framings, understandings and responses', Global Environmental Change 29: 165-179. Available at: http://dx.doi.org/10.1016/j.gloenvcha.2014.09.006]

\subsection{Public framings}

This section explores how study participants framed marine climate change issues based on the open elicitation survey responses about marine environments more generally and by drawing on the discussions, as well as the way in which participants responded to scientific definitions of the issue, in workshop deliberations.

Following some socio-demographic questions, and one about the severity of issues globally, survey respondents were asked: "When you think about the coastline or the sea, what are the three most important environmental matters that come to mind?", and were allowed three entries of maximum four words each. Most respondents provided three associations (although, for each elicitation, 1.3\%, $3 \%$ and $6.1 \%$ respectively did not). Associations were expressed as either single word responses (e.g. 'refuse') or short phrases (e.g. 'rubbish on beaches and in sea'). Among the first responses, 41 distinct associations were identified (the codebook is available from the authors). As shown in Figure 1, 'coastal erosion' was the most frequently mentioned association ( $27.5 \%$ of responses), closely followed by 'pollution' (20.8\%), denoted as such by respondents. These two categories constitute nearly half of all first responses. Other associations related to contamination included 'oil pollution' (5.7\%), 'water pollution' (4.7\%), 'rubbish' (4\%), 'sewage' (2.7\%), and litter (1.4\%). Juxtaposing references were made to 'water cleanliness' (3.1\%), 'beach cleanliness' $(2.4 \%)$ and 'cleanliness' (1.9\%). The clear finding is that, in relation to marine environments, climate change explicitly, on this occasion, was not the most salient issue for most people. Only $3.6 \%$ of respondents mentioned 'climate change' directly (exact phrasing or similar wording); small proportions referred to other impacts possibly related to climate change such as sea level rise (5.4\%) and flooding (2.1\%). Fishing (fish stocks, $1.2 \%$; overfishing, $2.2 \%$ ) and wildlife (2.3\%) were also mentioned; other associations were referred to by less than $1.4 \%$ of respondents.

Second and third responses largely reflect the associations provided in the first elicitation (see Figure 1). Not surprisingly, more categories emerged as respondents provided their second and third choice responses and some of the associations mentioned in the first instance become less prevalent. 
[Pre-print - authors' accepted manuscript version. Please cite as the published version: Chilvers, J., Lorenzoni, I., Terry, G., Buckley, P., Pinnegar, J.K. \& Gelcich, S. (2014) 'Public engagement with marine climate change issues: (Re)framings, understandings and responses', Global Environmental Change 29: 165-179. Available at: http://dx.doi.org/10.1016/j.gloenvcha.2014.09.006]

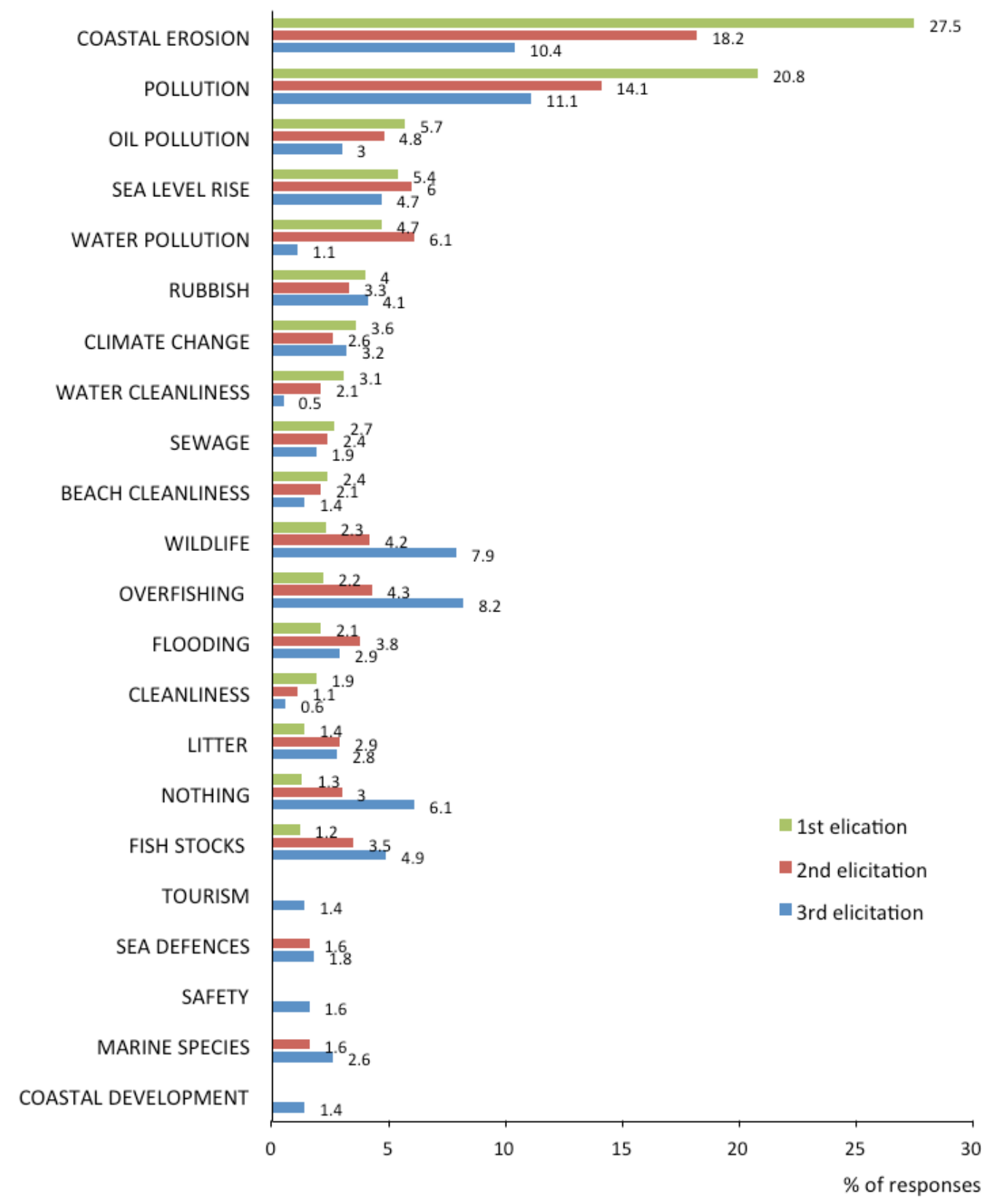

Figure 1. Most frequent associations of environmental matters associated with the coastline / sea for the national sample, elicited by the question 'When you think about the coastline or the sea, what are the three most important environmental matters that come to mind?'. 'Don't know' responses were very low $(2.9 \%, 1.5 \%$ and $1.1 \%$ respectively for first, second and third elicited occasions). $\mathrm{N}=1001$ (UK). 
[Pre-print - authors' accepted manuscript version. Please cite as the published version: Chilvers, J., Lorenzoni, I., Terry, G., Buckley, P., Pinnegar, J.K. \& Gelcich, S. (2014) 'Public engagement with marine climate change issues: (Re)framings, understandings and responses', Global Environmental Change 29: 165-179. Available at: http://dx.doi.org/10.1016/j.gloenvcha.2014.09.006]

Associations elicited by this question from respondents residing in the East of England and those living on the eastern coast show similarities with the national sample, with a few variations. Among the East of England respondents, the most common word association (as expressed in the first elicitation occasion) continues to be 'coastal erosion' (40.2\%), followed by 'pollution' (15.1\%). Second elicitations to this question reveal a similar pattern (19\% of respondents to this question mentioning 'coastal erosion', $14.6 \%$ 'pollution'). Responses to the third elicitation occasion to this question start revealing other matters which are salient but not predominant: in addition to the ubiquitous 'pollution' (13.8\%), frequent responses also feature 'overfishing' (13.3\%) and 'wildlife' (13.5\%). For the small sample of respondents living on the eastern coast, 'coastal erosion' $(51.4 \%$ of responses in the first elicitation occasion, $14.1 \%$ in the second) was paramount. This was followed by 'sea level rise' (mentioned by $9.5 \%$ of respondents in the first elicitation, $7.4 \%$ in the second); 'flooding', 'pollution' and 'water pollution' (17.5\%, 16\%, 14.9\% in the second elicitation), 'overfishing' and 'wildlife' ( $12.9 \%$ and $15.2 \%$ in the third elicitation).

These results were largely reflected in the qualitative data from the deliberative workshop. At the beginning of the process when participants openly discussed marine environments, the most predominant environmental issues relating to the coastline and the sea were again pollution and erosion, with overfishing and effects on wildlife also evident. Previous studies have shown how UK publics often associate marine environments with pollution (Howard and Parsons, 2006; Mee et al, 2008), a connection that participants often made based on personal experience, as this quote illustrates:

"I've noticed that the beaches are dirtier, there's more stuff washing up that is clearly what people have put down toilets, that hasn't actually disintegrated." (Tanya, Norwich - Session 1)

Further insights into public framings are provided through the ways in which workshop participants responded to scientifically defined information and definitions of the issues in question. Information presented in the participatory workshop - in presentations by scientists and in posters - defined marine climate change impacts in terms of scientifically derived categories such as sea temperature changes, sea level rise and ocean acidification, which were informed by a scientific review of marine climate change impacts in Europe (see Heip et al. 2011). While participants were very able to engage with these impact categories (as illustrated in section 4.2 below), some openly reflected upon and at times challenged these compartmentalised issue definitions. This was expressed, for example, through 
[Pre-print - authors' accepted manuscript version. Please cite as the published version: Chilvers, J., Lorenzoni, I., Terry, G., Buckley, P., Pinnegar, J.K. \& Gelcich, S. (2014) 'Public engagement with marine climate change issues: (Re)framings, understandings and responses', Global Environmental Change 29: 165-179. Available at: http://dx.doi.org/10.1016/j.gloenvcha.2014.09.006]

several workshop participants emphasising that all of the impacts under discussion and underlying (social and physical) processes, were deeply interconnected:

“It’s all linked, isn't it?” (Barbara, North Norfolk coast - Session 2)

“Everything that we've talked about today and everything I feel I know on the subject would suggest that all those [processes] are interrelated." (Donald, Norwich - Session 2)

Some participants went further in expressing climate change, as well as marine climate change impacts in particular, as part of a wider problem: that of human beings' relationship with their environments. For example, one participant explicitly rejected the dominant framing of climate change as a stand-alone issue in the following way:

"Humans, as a rule, we should just live by the fact that you don't mess up your own backyard, so let's go ... with the actual stuff that people can focus on. If you clean up the pollution, generally you'll go back through the chain of all the other things that pollute, possibly pump out the carbon dioxide etcetera, which would then hopefully reduce these issues, if they exist, that we're actually going through. So I personally think the whole concept and term [climate change] is wrong and we need to go back to basics in terms of what the environment is and what we need to do with it." (Joseph, Norwich - Session 1)

The findings presented in this section from both the wider public survey and in-depth group discussions support each other in revealing that although climate change impacts play some part, they are not necessarily foremost in the way that the research participants framed marine and coastal environment-related issues. Furthermore most participants did not tend to compartmentalise the issues involved or view them in technically-defined terms. Rather most respondents viewed climate change impacts in a more situated, joined up and relational way, in the context of other more immediate concerns in their daily lives and issues affecting marine environments more widely.

\subsection{Public understandings}

This section brings together findings on public knowledge and understandings of marine climate impacts and the salience of these issues to the public. We draw on data where public views on marine climate impacts in particular were directly elicited in the survey and qualitative research. In many 
[Pre-print - authors' accepted manuscript version. Please cite as the published version: Chilvers, J., Lorenzoni, I., Terry, G., Buckley, P., Pinnegar, J.K. \& Gelcich, S. (2014) 'Public engagement with marine climate change issues: (Re)framings, understandings and responses', Global Environmental Change 29: 165-179. Available at: http://dx.doi.org/10.1016/j.gloenvcha.2014.09.006]

respects this confirms the findings about public framings given above while providing more detailed insights into the degree of public salience and concern of different impacts.

After a question on the causes of climate change, survey respondents were asked about affective associations (see Szalay and Deese, 1978; Peters and Slovic, 1996): "Which three things, if any, come to mind when you think about the impacts of climate change on the coastline or the sea?" and to rate each self-reported association as 'a good thing', 'neither a good nor a bad thing', and 'a bad thing'. The word associations overall reveal particularly salient references (see Figure 2): most notably those to 'sea level rise' and 'coastal erosion', followed by 'flooding' (respectively $32.1 \%, 27.4 \%$ and $8.1 \%$ of responses in the first elicitation). The difference with the previous question where references to climate change in relation to the marine environment were unsolicited is evident: the threat of sea level rise is more to the forefront of respondents' thoughts in regards to the sea. The responses to this question are revealing in other ways: second and third responses suggest individuals also relate impacts of climate change with contamination ('pollution'), impacts on the natural ('weather', 'temperature rise', 'melting icecaps', 'wildlife', 'marine species') as well as human ('coastal communities') environments. The average affect assigned to the most common first associations is consistently negative (ranging from -0.57 to the absolute -1 attributed to pollution). This indicates that respondents associate negative connotations and feelings to the impacts they most frequently mentioned in relation to impacts of climate change on the coastline / sea; to one all respondents attributed negative associations (e.g. 'pollution'), to others respondents were either negative or neutral (indicated by a lower mean and higher standard deviation, see Figure 2).

For respondents living in the East of England (those who indicated that they lived in the East of England), most paramount associations were 'sea level rise' (37.5\% at first elicitation, $15.8 \%$ at second), 'coastal erosion' (35.4\% at first elicitation, 17.2\% at second), 'flooding' (13.6\% at second elicitation), 'wildlife', 'pollution' and 'nothing' (respectively 12.3\%, 12.4\% and 10.3\% at the third elicitation). These mirrored the associations offered by respondents living on the eastern coast, which in fact appear even more accentuated: 'sea level rise' and 'coastal erosion' were mentioned by $48.3 \%$ and $27.3 \%$ of respondents in the first opportunity for association in this question. 'Coastal erosion' again was mentioned frequently in the second association (31.3\%) as well as 'wildlife' $(10.7 \%)$. Third associations provided more varied responses: 'wildlife' (13.4\%), 'pollution' (13.9\%) and 'flooding' $(12.4 \%)$. 
[Pre-print - authors' accepted manuscript version. Please cite as the published version: Chilvers, J., Lorenzoni, I., Terry, G., Buckley, P., Pinnegar, J.K. \& Gelcich, S. (2014) 'Public engagement with marine climate change issues: (Re)framings, understandings and responses', Global Environmental Change 29: 165-179. Available at: http://dx.doi.org/10.1016/j.gloenvcha.2014.09.006]

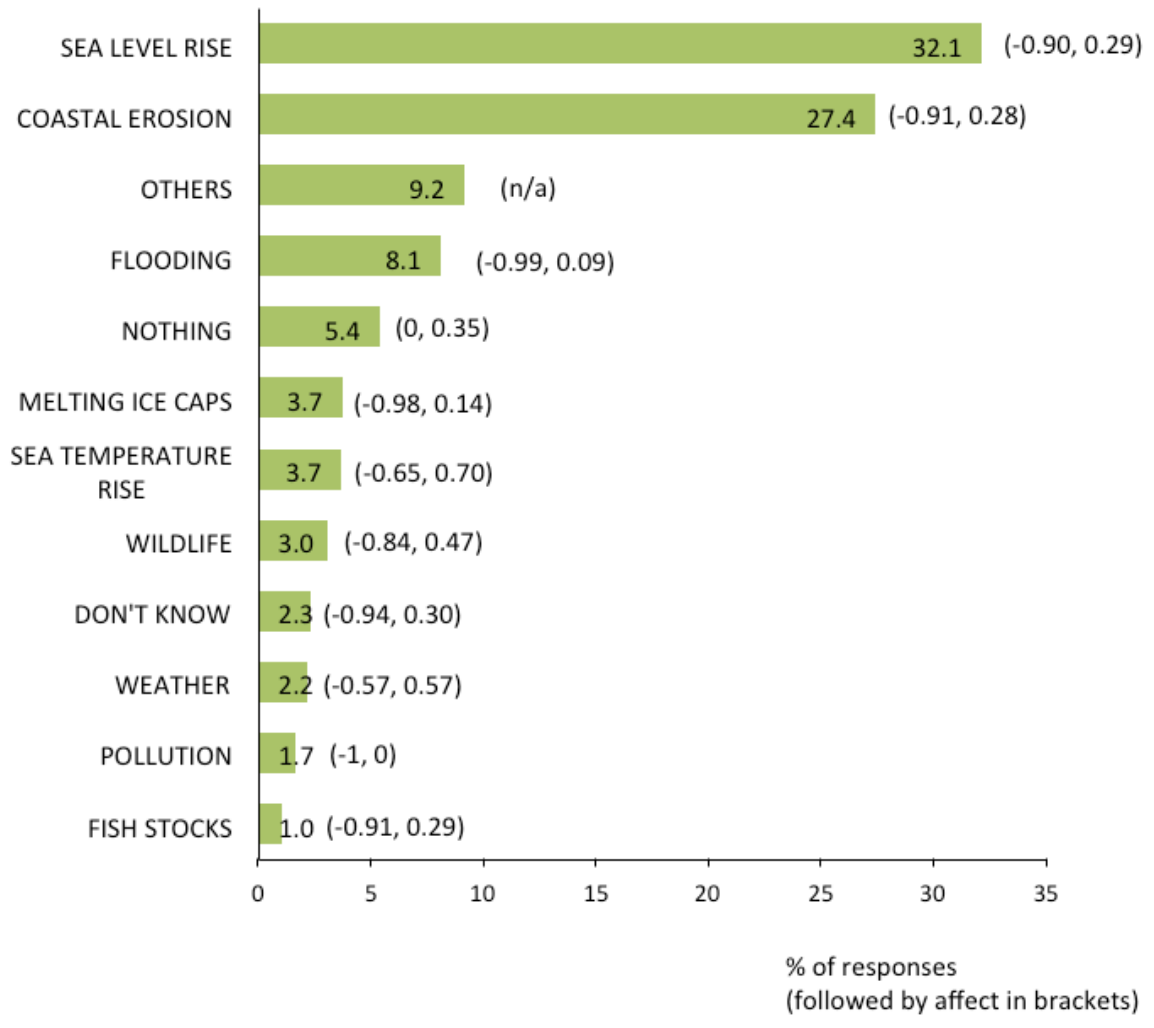

Figure 2. Most frequent ( $\geq 1 \%$ ) first elicitation associations of impacts of climate change on the coastline / sea in response to the question "Which three things, if any, come to mind when you think about the impacts of climate change on the coastline or the sea?" Mean affect (elicited on a scale from -1 "a bad thing" to +1 "a good thing") is indicated in brackets next to each percentage response bar, followed by the standard deviation. $\mathrm{N}=1001$ (UK). Those mentioned by less than $1 \%$ of respondents are grouped as 'others'; these included 'coastal communities' $(0.8 \%$, mean affect -0.70$)$, 'marine species' $(0.8 \%$, mean affect -1$)$, 'change in ocean currents' $(0.4 \%$, mean affect -1$)$, 'tsunami' $(0.4 \%$, mean affect -1$)$ and 'climate change' $(0.1 \%$, mean affect -1$)$.

Responses to these open elicitations indicate that individuals are to some extent already relating to marine environmental issues, with and without consideration of climate change, and in their own terms raise a diverse and relevant range of issues. It is interesting that one of the most dominant associations is 'coastal erosion', preceded by 'pollution' in regards to general impacts on marine environments (Figure 1) and 'sea level rise' with regards to climate change impacts (Figure 2). 
[Pre-print - authors' accepted manuscript version. Please cite as the published version: Chilvers, J., Lorenzoni, I., Terry, G., Buckley, P., Pinnegar, J.K. \& Gelcich, S. (2014) 'Public engagement with marine climate change issues: (Re)framings, understandings and responses', Global Environmental Change 29: 165-179. Available at: http://dx.doi.org/10.1016/j.gloenvcha.2014.09.006]

Respondents living in the East of England, and the sub-sample of these living on the eastern coast refer consistently to sea level rise and flooding when prompted about climate change impacts.

Further insights into the public salience of marine climate impacts were obtained by eliciting respondents' reported informedness and concern in relation to a set of pre-defined categories. These categories where informed by a science review of marine climate change impacts undertaken alongside the public survey (see Heip et al. 2011) to ensure good coverage of relevant impacts. The findings in Figures 3 and 4 support the above analysis of public framings: across the national UK sample, as well as in sub samples (East of England and the Eastern coast), respondents' prevalent concerns (70-80\%) are about coastal erosion and coastal flooding (which most respondents professed to be most informed about), closely followed by sea level rise and destruction of habitats. Concern about coastal erosion reflects a recent Ipsos-Mori (2013) survey of UK publics, indicating that for high proportions of respondents coastal erosion was a serious problem now and likely in the future.

Relatively lower levels of concern were manifested by respondents regarding less localised impacts (e.g. melting ice, changes in frequency of extreme events, 64-65\%), possibly indicating they are perceived to be less salient and tangible; however, respondents in the East of England and on the eastern coast of the country expressed concern about these. This seems to suggest some geographical variability in salience, although we are cautious in our interpretation as respondent numbers in these areas (East of England, and eastern coast) in our samples are low.

As Figures 3 and 4 illustrate, there is some correspondence and relatively consistent ranking of impacts between levels of informedness and concern. Indeed, Spearman rank-order correlations among all the concern and informedness items are positive, low $(\rho \leq .424)$ and significant, indicating there are direct associations between them. Impacts with high expressed levels of informedness are also of high concern (e.g. coastal erosion, $\rho=.333, \mathrm{p}<.01$; coastal flooding, $\rho=.307, \mathrm{p}<.01$ ). The five impacts of lowest informedness (i.e. between 5-20\%: ocean acidification, jellyfish blooms/swarms, effects of marine invasive species, changes in distribution of wildlife, and ocean current changes) are also the five lowest in terms of concern (ranging between 40-54\%). There are some inconsistencies in this overall pattern, however: for instance, low informedness about destruction of habitats $(27-30 \%$ across all geographic scales) vs. high concern (65-72\%). 
[Pre-print - authors' accepted manuscript version. Please cite as the published version: Chilvers, J., Lorenzoni, I., Terry, G., Buckley, P., Pinnegar, J.K. \& Gelcich, S. (2014) 'Public engagement with marine climate change issues: (Re)framings, understandings and responses', Global Environmental Change 29: 165-179. Available at: http://dx.doi.org/10.1016/j.gloenvcha.2014.09.006]

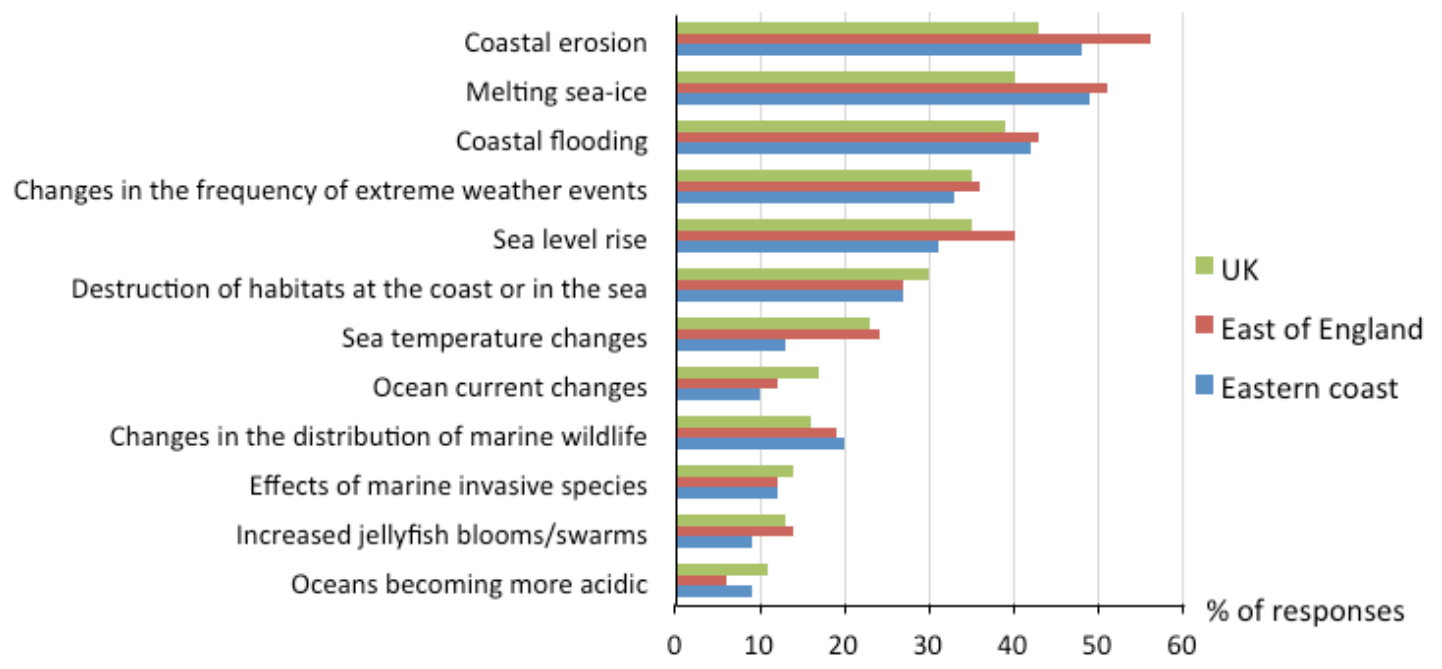

Figure 3. Informedness about climate change impacts on marine environments, elicited by the Likertscale question 'How informed do you feel about each of the following? The illustration combines responses indicating 'very well informed' and 'informed' which are expressed as percentages of total responses to the question ( $\mathrm{N} U K=1001 ; \mathrm{N}$ East of England $=78 ; \mathrm{N}$ Eastern coast $=43$ ).

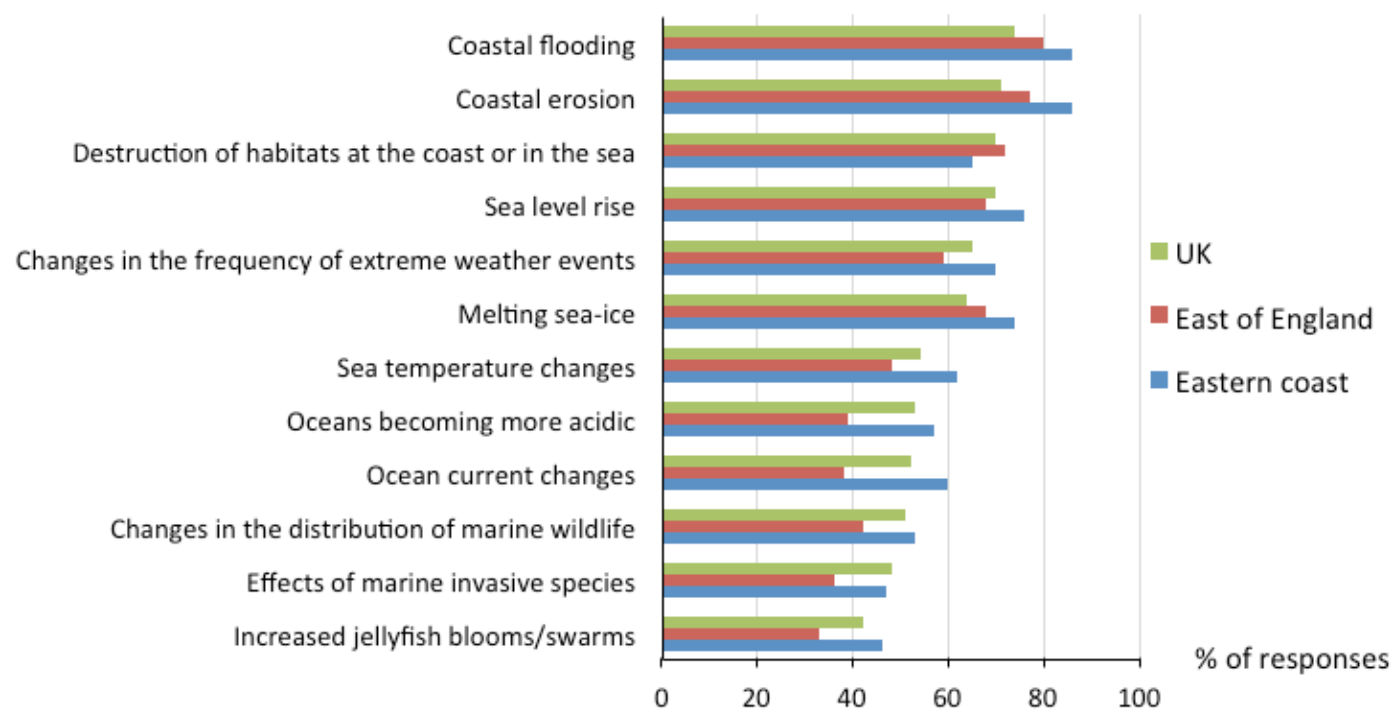

Figure 4. Concern about climate change impacts on marine environments elicited by the Likert-scale question 'Now please indicate to what extent do you feel concerned about each of the following'. The illustration combines responses indicating 'very concerned' and 'concerned' expressed as percentages of total responses to the question $(\mathrm{N} \mathrm{UK}=1001$; $\mathrm{N}$ East of England $=78$; $\mathrm{N}$ Eastern coast $=43$ ). 
[Pre-print - authors' accepted manuscript version. Please cite as the published version: Chilvers, J., Lorenzoni, I., Terry, G., Buckley, P., Pinnegar, J.K. \& Gelcich, S. (2014) 'Public engagement with marine climate change issues: (Re)framings, understandings and responses', Global Environmental Change 29: 165-179. Available at: http://dx.doi.org/10.1016/j.gloenvcha.2014.09.006]

Overall these data indicate that marine climate change impacts that are more immediate, visible, tangible and 'available' (in that they form part of common discourses around marine environments and climate change) tend to be more salient (i.e. show higher expressed levels of informedness and concern) for publics in the UK, which supports the findings of existing studies noted in Section 2 (e.g. O’Neill and Hulme, 2009).

This inference was widely confirmed by a number of participants in workshop deliberations. For example, some participants attributed the visibility of coastal erosion to the physical proximity of a vulnerable coastline and consequent local media coverage (in contrast to ocean acidification):

\footnotetext{
"Because of where we are near the coast and we are in relatively low lying lands... it's something that is higher up in our consciousness than the acidity of the sea, we don't really hear that on the news in the evening... It's local and immediacy that make you more concerned about something." (Carrie, Norwich - Session 2)
}

Underlying explanations for expressed salience and concern are clearly complex and demand deeper insights into the nature of public understandings, knowledge and beliefs in relation to marine climate change impacts. In this regard the survey provided evidence that UK publics have a good sense of the scientific estimates and information on the issue. For instance, in response to a question on future projected sea level rise survey respondents accorded well with scientific opinion, given the range of uncertainty that exists: $35.9 \%$ of respondents thought that waters would rise by $10 \mathrm{~cm}$ to $1 \mathrm{~m}$ by end of the century, with a further $24.7 \%$ saying the figure would be between 1 and $5 \mathrm{~m}$ (of the remainder, $21.2 \%$ indicated the rise would be less than $10 \mathrm{~cm} ; 10.2 \%$ maintained the rise would be $5 \mathrm{~m}$ to just under $10 \mathrm{~m}, 4 \%$ stated that the rise would be $10 \mathrm{~m}$ or more; and $4 \%$ indicated there would be no rise in sea level over the century). The IPCC (2013) projects a $26-82 \mathrm{~cm}$ rise in sea level over the same period. These findings are in contrast with other studies (e.g. Poortinga \& Pidgeon, 2003; Reynolds et al., 2010), which emphasise low levels of knowledge and understanding about climate change and its impacts amongst publics.

Public understandings of marine climate impacts are about much more than acquiring scientific knowledge, however. In-depth qualitative data further reveal the nature of these understandings and help explain survey findings about framings and concerns presented above. A significant analytical code derived from workshop deliberations was the critical role ascribed to experiential and local knowledge in shaping public understandings of marine environmental change such as marine climate 
[Pre-print - authors' accepted manuscript version. Please cite as the published version: Chilvers, J., Lorenzoni, I., Terry, G., Buckley, P., Pinnegar, J.K. \& Gelcich, S. (2014) 'Public engagement with marine climate change issues: (Re)framings, understandings and responses', Global Environmental Change 29: 165-179. Available at: http://dx.doi.org/10.1016/j.gloenvcha.2014.09.006]

impacts. Several participants gave examples of how their own personal experiences had shaped their understandings of marine environmental change, in the same way that sociologists and other social scientists have repeatedly shown how personal experience, whether direct or vicarious, is a key aspect of lay knowledge on environmental issues (cf. Wynne, 1991; Irwin, 1995; Myatt-Bell et al., 2002). For instance a seaman described how he had noticed an increase in maximum wave heights over the years, while another participant talked about changes in fish species distribution due to rising sea temperatures thus illustrating the importance of vicarious experiences and personal interactions in shaping knowledge, in this case through a fisherman she knew:

"Every year it seems to be increasing, the amount of wave action on our coast." (Ralph, North Norfolk coast - Session 1)

“There's a lot of change in the fish economy. I'm quite good friends with [a fisherman] who says people don't want to buy species of fish they are not familiar with. He says he is running out of money because he is catching things that people don't want to eat." (Zahra, North Norfolk coast - Session 1).

In-depth group discussions also revealed how participants' perceptions of marine climate change impacts were also closely tied to their sense of personal risk. Within this code, some workshop participants clearly stated that threats perceived as spatially and temporally remote received lower recognition, for instance:

"If it's miles away, I'm not that bothered, as I say the closer to home it is, the more it hurts." (Michael, Norwich - Session 2)

Other participants acknowledged that although some risks may be directly borne disproportionately by certain groups within society, the overall risk becomes distributed among many thus being incurred indirectly. This closely relates to an important code on moral and equity considerations regarding other people and species. Here some participants expressed an affective connection with distant places and peoples affected by climate change, and the moral need to take responsibility for such impacts, as reflected by this quote for example:

"Most of us are in a privileged position, whereas 75 to 200 million people by 2020 will be experiencing shortages of fresh water. That's a real impact, they'd be worried. We've got blue 
[Pre-print - authors' accepted manuscript version. Please cite as the published version: Chilvers, J., Lorenzoni, I., Terry, G., Buckley, P., Pinnegar, J.K. \& Gelcich, S. (2014) 'Public engagement with marine climate change issues: (Re)framings, understandings and responses', Global Environmental Change 29: 165-179. Available at: http://dx.doi.org/10.1016/j.gloenvcha.2014.09.006]

flag beaches so we're all right, do you see what I'm getting at? ... That's where I think it's as much a moral issue as anything." (Donald, Norwich - Session 2)

\subsection{Public responses}

The final theme emerging from the survey, and reinforced by qualitative data, relates to study participants' views of responses to climate change impacts (including marine impacts) taken by themselves and by others (including other publics).

The clear finding from both survey and qualitative data is that when it comes to responding to climate change impacts, publics emphasised climate change mitigation actions over adaptation. As shown in Figure 5, in considering the 'most effective actions individuals should take to reduce and cope with the impacts of climate change', most respondents highlighted behavioural changes relating to mitigation, with the two most frequently mentioned being reducing energy use at home and using energy from sustainable sources (66\% and $56 \%$ of responses respectively at UK level). This contrasts quite markedly with the behavioural responses that might be taken at an individual or household-level to adapt to the impacts of marine climate change: far fewer UK respondents identified preparing homes against flooding $(16 \%)$, moving to a less flood prone area (13\%) or purchasing flood insurance $(5 \%)$.

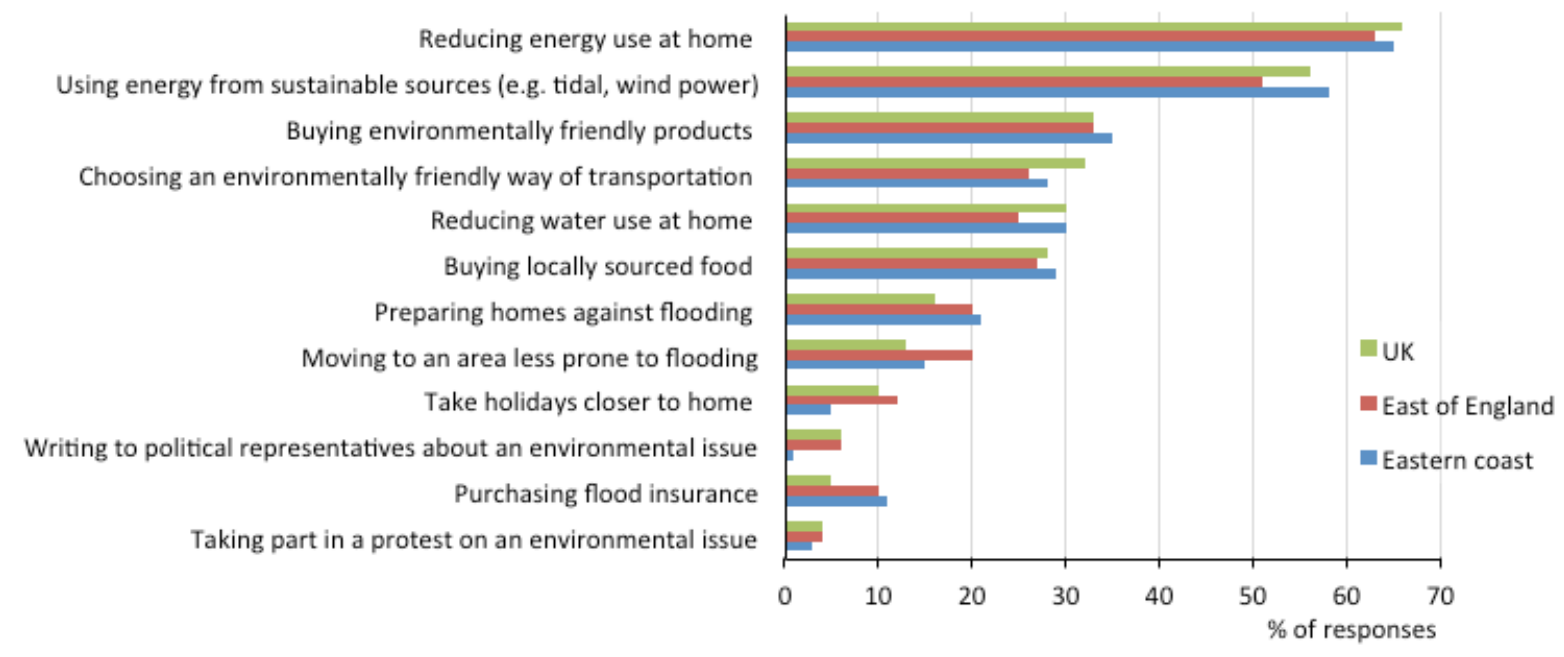

Figure 5. Actions others should take on mitigation and adaptation, expressed as percentage of responses to the question 'From the list below, please select the three most effective actions you feel individuals should take to reduce and cope with the impacts of climate change' at UK $(\mathrm{N}=1001)$, East of England $(\mathrm{N}=78)$ and Eastern coast $(\mathrm{N}=43)$ levels. 
[Pre-print - authors' accepted manuscript version. Please cite as the published version: Chilvers, J., Lorenzoni, I., Terry, G., Buckley, P., Pinnegar, J.K. \& Gelcich, S. (2014) 'Public engagement with marine climate change issues: (Re)framings, understandings and responses', Global Environmental Change 29: 165-179. Available at: http://dx.doi.org/10.1016/j.gloenvcha.2014.09.006]

The survey also indicates discrepancies between what people claim are the most effective ways of addressing climate change and its impacts, and the actions they reportedly take in their personal lives (see Figure 6). One explanation for these discrepancies, for example in the case of using energy from sustainable sources, is prevailing barriers and infrastructural constraints to action, which workshop discussions highlighted as including: financial constraints, reduced sense of personal agency, and limited service provision (cf. Shove, 1998; Lorenzoni et al., 2007). It is important to note, however, that notwithstanding limits to the reliability of self-reported pro-environmental actions, the data provide strong evidence that citizens are responding to the challenge of living more sustainably. This is reflected in large proportions of individuals at national level reportedly reducing home water use (76\%), buying environmentally friendly products (72\%) and locally sourced food (69\%), and even taking more local holidays (48\%). The two subsamples (individuals in the East of England and those living on the eastern coast) exhibit very similar responses to those at the national level (see Figures 5 and 6).

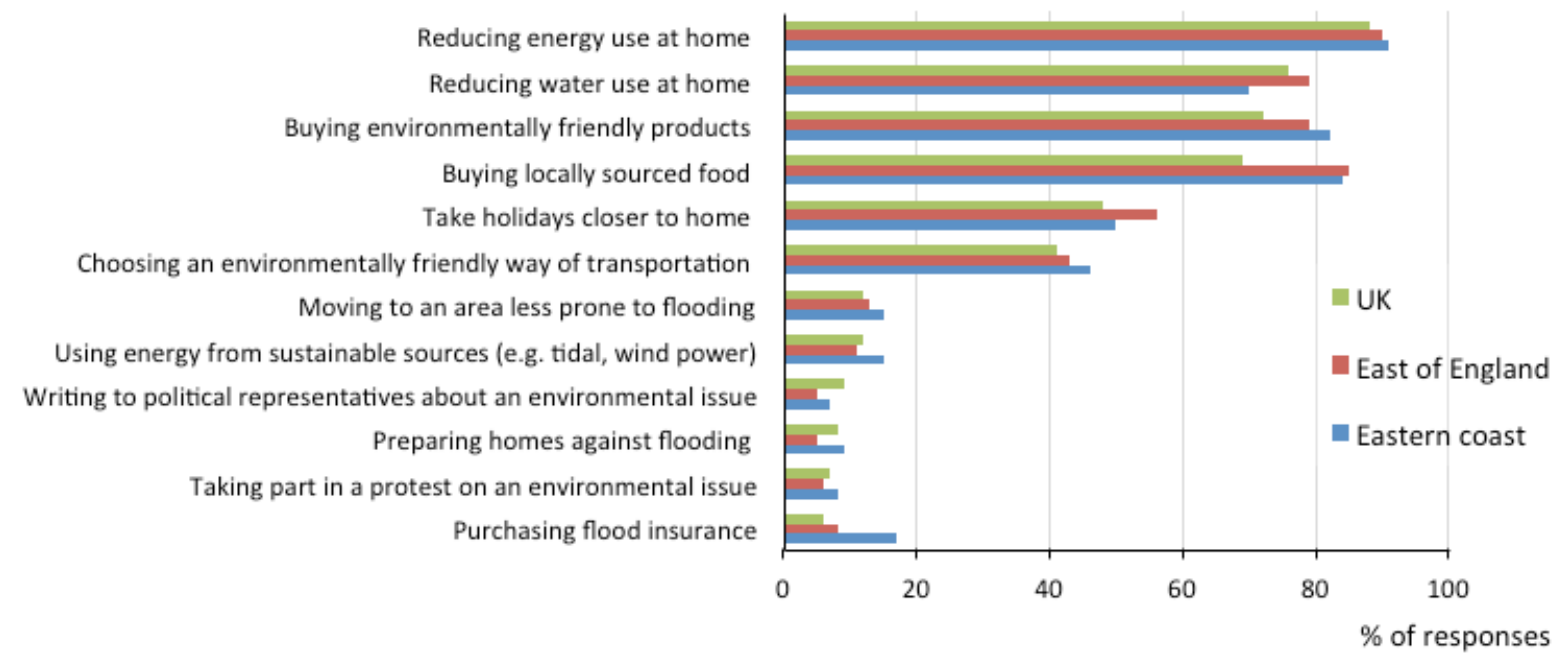

Figure 6. Mitigation and adaptation actions individuals had taken, expressed as a percentage of 'yes' responses to the question 'Please indicate whether you have taken any of the following actions to reduce and cope with the impacts of climate change', at UK ( $\mathrm{N}=1001)$, East of England $(\mathrm{N}=78)$ and Eastern coast $(\mathrm{N}=43)$ levels.

These actions reiterate respondents' more holistic and integrated views of environmental problems. Further analyses however suggest that respondents related differently to the items in this question which focused on reducing and coping with the impacts of climate change, namely on mitigation, adaptation and sustainability more generally. The low Cronbach $\alpha$ values $(<0.8)$ may indicate 
[Pre-print - authors' accepted manuscript version. Please cite as the published version: Chilvers, J., Lorenzoni, I., Terry, G., Buckley, P., Pinnegar, J.K. \& Gelcich, S. (2014) 'Public engagement with marine climate change issues: (Re)framings, understandings and responses', Global Environmental Change 29: 165-179. Available at: http://dx.doi.org/10.1016/j.gloenvcha.2014.09.006]

individual variability in the responses to the items, which may in turn be a result of the question wording (i.e. that individual variability in the responses was fostered by the wording of the questions). Additional Spearman rank-order correlations show a discrepancy between actions respondents have taken themselves and those they feel others should take to reduce and cope with the impacts of climate change: the same type of adaptation action at the general individual level (purchasing flood insurance, preparing homes against flooding, moving home) is negatively and weakly correlated with the same action taken by individual respondents $(\rho \leq-.119, \mathrm{p}<.01)$.

The tendency for survey respondents to ascribe lower priority to adaptation responses was also confirmed in the in-depth group deliberations despite some participants living in locations at high risk to marine climate change impacts. This is broadly consistent with the findings of other studies in high risk communities, such as those vulnerable to coastal flooding (e.g. Harvatt et al., 2011; Zsamboky et al., 2011), which also found that individuals did not regard flood risk as important or urgent. The indepth qualitative data provides deeper insights into the underlying reasons for this. These include the argument put forward by some participants that adaptation is a defeatist approach and the 'easy' option in comparison to various possible mitigation actions (an argument that has long permeated international negotiations on climate change; Pielke et al., 2007), as the following participant noted:

"It's interesting to even think of these as being in any way mutually exclusive, because you could certainly do either, and then because of the way things are going, you'll probably be required to do the adaption bit anyway. It's just worrying to think that you might go to adaption as a way of not doing anything else.” (Donald, Norwich - Session 3)

This was intertwined with feelings of complacency, a disregard of immediate threats, and a sense of limited personal agency to respond to marine climate impacts such as sea level rise and coastal flooding:

"I'm conscious about some of the issues, but I can't see how I can actually do something to affect them personally, like I can't change coastal erosion; I can't change the water levels." (Michael, Norwich - Session 3)

Mitigation actions were at the forefront of participants' discussions about tackling climate change, which may reflect it being a dominant discourse in climate change communications in recent years, thus crowding out adaptation concerns. One further explanation evident in workshop deliberations 
[Pre-print - authors' accepted manuscript version. Please cite as the published version: Chilvers, J., Lorenzoni, I., Terry, G., Buckley, P., Pinnegar, J.K. \& Gelcich, S. (2014) 'Public engagement with marine climate change issues: (Re)framings, understandings and responses', Global Environmental Change 29: 165-179. Available at: http://dx.doi.org/10.1016/j.gloenvcha.2014.09.006]

was that participants are already adapting to climate change in small ways but that these practices are often incommensurable with the way adaptation responses are framed by science and policy institutions (and were presented to respondents in the survey). This also contrasts with the dominant, policy-relevant discourses focussed on technical adaptation (e.g. Yohe and Tol, 2002). In group discussions adaptation was seen as a feature of everyday live and routine decisions made by members of the public, for example in relation to where one lives and consuming fish:

"I would assume that everybody here knows about the areas on the Norfolk coast which are in most danger of erosion and therefore would not probably look at buying a property there, so that's adapting because you're not thinking I'm going to live here ... I suppose we're all doing that, we're all making choices every day about what we do so we are adapting." (Tanya, Norwich - Session 3)

"Sea bass are becoming more popular: where I live at Sea Palling, there's a lot more sea bass there. People do like sea bass". (Daniel, North Norfolk coast - Session 3)...

"It's cheaper as well, it used to be a luxury and now you can afford to get it, and it's beautiful fish, as well." (Zahra, North Norfolk coast - Session 3)

\section{Discussion and conclusions}

In response to a relative paucity of literature on how publics relate to marine climate change issues, this paper reports on the first large-scale survey on the subject, linked with in-depth qualitative research. In the following discussion and concluding statements we draw together the key findings from across the above analysis. In doing this we further interpret these findings in relation the existing literature and reflect on the significance and limits of the mixed-method approach used in the study. We focus on three aspects in particular. First, we review our findings on how public participants frame and understand marine climate change issues, considering underlying explanations for the patterns observed. Second, we reflect on the seemingly counterintuitive finding that, even in high-risk areas, public participants in our study prioritised mitigation over adaptation responses. Third, we consider the implications of our findings for future research and practice of public engagement with marine climate change impacts.

An important component of our survey approach was the initial open elicitation questions which sought to more openly enable publics to provide their own framings of marine climate change issues. 
[Pre-print - authors' accepted manuscript version. Please cite as the published version: Chilvers, J., Lorenzoni, I., Terry, G., Buckley, P., Pinnegar, J.K. \& Gelcich, S. (2014) 'Public engagement with marine climate change issues: (Re)framings, understandings and responses', Global Environmental Change 29: 165-179. Available at: http://dx.doi.org/10.1016/j.gloenvcha.2014.09.006]

To our knowledge this is the first time such a technique has been used to explore extensive public views on this topic. It shows that when it comes to marine environmental issues more generally, climate change in particular is not the most important matter of concern for most survey respondents, with pollution and costal erosion being more significant in all geographical regions analysed (Section 4.1). This is not to say that climate change impacts were not mentioned - coastal erosion can be interpreted as a climate change-related impact - but it suggests they were viewed in context of other marine environmental issues. Some care is needed in interpreting this finding, not least because survey data do not reveal how respondents related to the term 'marine environments', and whether this term encompassed climate change or vice versa. This is where results from the in-depth qualitative research, albeit drawn from one region of the UK, provide valuable additional insights into this dynamic. Openly framed discussions about marine environments in the first session of the deliberative workshop saw most participants initially identifying a range of issues including pollution, degradation of the natural environments, and coastal erosion. Climate change was not the most immediate issue for participants in these discussions. Responses to information and expertise on specific climate change impact categories in Session 2 adds weight to the evidence that most participants viewed climate change impacts as specific and specialist issues compared to their own situated experiences. Furthermore, some participants emphasised the interconnected nature of marine climate change issues as part of wider concerns about environment and humanity. Taken together, this evidence from across the mixed methods leads us to conclude that public participants involved in this research predominantly approached marine climate change impacts 'in context', in a situated and relational way, making connections between them and in relation to other matters of concern in their everyday lives. This conclusion echoes work in social studies of science and society that shows publics to be simultaneously entangled in and associated with multiple networks and 'matters of concern' in situ and in multivalent ways (Wynne, 1993; Latour, 2004). It also concurs with recent studies that emphasise the importance of context in public perceptions of climate change more generally (e.g. Capstick and Pidgeon, 2014) and emerging work on marine climate impacts more specifically (e.g. Gee, 2010; Combest-Friedman et al., 2012; Moser, 2014).

Related to these points on framing, the above analysis has also furthered insights into public knowledge and understanding of marine climate change issues. At a time when international attention is increasingly focussing on the sustainability of marine environments (e.g. IPCC 2014; the recently instituted Global Ocean Commission), received wisdom is often that publics lack understanding and connection with marine issues which are in some respects distant and remote (e.g. Heip et al 2011). Through encompassing both coastal and sea environments in the scope of our study (as elicited in the 
[Pre-print - authors' accepted manuscript version. Please cite as the published version: Chilvers, J., Lorenzoni, I., Terry, G., Buckley, P., Pinnegar, J.K. \& Gelcich, S. (2014) 'Public engagement with marine climate change issues: (Re)framings, understandings and responses', Global Environmental Change 29: 165-179. Available at: http://dx.doi.org/10.1016/j.gloenvcha.2014.09.006]

survey) we offer important insights into the patterning of public understanding. The first observation in this regard is that the level of knowledge and engagement with marine environmental issues was perhaps higher than expected: open elicitation survey responses and initial in-depth group discussions showed respondents raising diverse marine environmental issues without receiving prior information (Section 4.1); and survey responses showed moderate levels of public awareness across most climate impact categories in addition to some level of engagement with scientific information on these topics (Section 4.2). Emerging strongly in relation to this, from analysis of both survey and in-depth group discussions, is that public understandings of marine climate impacts were mainly shaped by personal experience, the visibility and proximity of impacts and perceived risk, and sense of morality regarding other people and species. Awareness and concern was highest for impacts that are more visible, tangible and 'available' (in that they form part of common discourses around marine environments and climate change) - for example sea-level rise and coastal erosion were the more prominent perceived threats compared to impacts like ocean acidification, sea temperature change and effects of marine invasive species. Qualitative data added further insight as illustrated through representative testimonies from workshop participants' talk (in Sections 4.1 and 4.2). While not exclusively so, there is a clear spatial dimension to this study's findings of public engagement, with impacts 'close to the coast' being more immediately apparent to participants than those 'out to sea'. This resonates with recent studies emphasising the importance of experience and place attachment in public perceptions of climate change risks (e.g. Harvatt et al. 2011; Quinn and Adger, 2011; Carlton and Jacobson, 2013; Devine-Wright, 2013).

A particularly striking finding from our analysis is the expressed low importance of adaptation relative to mitigation responses. Even respondents most at risk, such as communities living in areas vulnerable to coastal erosion or flooding (as discussed in Section 4.3), considered adaptation to be secondary in importance to mitigation, for a variety of reasons. This finding is supported by both survey responses, which show higher action and priorities attached to mitigation over adaptation, and expressions in workshop deliberations (Section 4.3). Whilst seemingly counter-intuitive, this finding is confirmed in other recent studies into public responses to marine climate impacts in the UK (e.g. Harvatt et al 2011, Zsamboky et al 2011) and in other countries (e.g. Moser, 2013). A reluctance to consider adaptation actions as equally important to mitigation actions at an individual level could indicate low perceived 'self-efficacy' and perceived 'adaptation efficacy' (see Grothmann and Patt, 2005), as well as highlighting the importance of place attachment, emotional connection, lack of personal efficacy and trust in institutions in mediating these responses (see Gee, 2010; Devine-Wright and Howes, 2010; Harvatt et al 2011;). However, in keeping with the above discussion of public 
[Pre-print - authors' accepted manuscript version. Please cite as the published version: Chilvers, J., Lorenzoni, I., Terry, G., Buckley, P., Pinnegar, J.K. \& Gelcich, S. (2014) 'Public engagement with marine climate change issues: (Re)framings, understandings and responses', Global Environmental Change 29: 165-179. Available at: http://dx.doi.org/10.1016/j.gloenvcha.2014.09.006]

framings, supporting evidence from workshop deliberations suggests that individuals are indeed adaptable and already adapting in diverse ways but do not openly associate their actions with formal or institutional definitions of adaptation and resilience building (for example: HM Government, 2013; IPCC 2014). Furthermore, the predominant global climate change policy discourse, including media coverage, has tended to emphasise mitigation over adaptation (Boykoff \& Roberts, 2007; Boykoff et al. 2013). Perhaps we are in fact witnessing an artificial separation created by our analytical lenses between adaptation and mitigation, whereas for publics these are meshed and closely related in daily practices and decision making at different levels. Moser (2013) has found a similar lack of public identification with formal institutional meanings of adaptation in the U.S. through in-depth focus group studies. In a recent review on the state of the art in communicating climate adaptation Moser (2014: 341) goes on to note the dearth of "systematic studies of how 'adaptation' is framed, understood and whether it is a compelling term in other regions of the world", which points to the importance of the UK results we have presented in this paper.

Finally, we consider the implications of our findings for research and practices of public engagement relating to marine climate impacts specifically, and climate change more generally. The first point to note is that our findings suggest that attempts at communication and engagement on marine climate change issues should be sensitive to people's own local circumstances and how they approach these issues in their own terms (cf. Carlton \& Jacobson, 2013). While similar recommendations have been made for climate change more generally (e.g. Lorenzoni et al., 2007; O’Neill and Nicholson-Cole, 2009), in this particular context our findings suggest the need to connect to other marine environmental issues and socio-cultural dimensions; communications narrowly framed in terms of technically or institutionally-defined marine climate impact categories are unlikely to connect as effectively with diverse publics. Following on from this, our second recommendation centres on the need to create spaces of 'collective experimentation' (Felt and Wynne, 2007; Callon et al., 2009) that builds on existing work in developing participatory arrangements for addressing coastal and marine climate change issues (see for example, Tompkins et al., 2008). Such spaces, through bringing decision-makers, scientists, and publics together on a more open and equal footing, can attempt to bridge disconnects and build reflexivity, such as over meanings of adaptation observed in our analysis where formal institutional framings contrast with more situated and vernacular public meanings.

In many respects the interactive deliberative process in our study represents such a space of coproduction in itself, which speaks to the wider public survey. While its primary purpose was to explore in much more depth what underpins and explains public responses to marine climate change 
[Pre-print - authors' accepted manuscript version. Please cite as the published version: Chilvers, J., Lorenzoni, I., Terry, G., Buckley, P., Pinnegar, J.K. \& Gelcich, S. (2014) 'Public engagement with marine climate change issues: (Re)framings, understandings and responses', Global Environmental Change 29: 165-179. Available at: http://dx.doi.org/10.1016/j.gloenvcha.2014.09.006]

rather than achieve 'representativeness', it took place in one region of the UK and does therefore have its limitations. Extending the in-depth component of this research to other geographic areas, whether that be in other regions of the UK (employing multi-site deliberative research approaches, such as those used by Corner et al. 2013 for example), or cross-cultural comparisons between countries, is thus a key area for further research. Having said this, it is important to maintain reflexive awareness of the constructed nature and partiality of all forms of participation and public representation (Marres, 2007; Brown, 2009; Chilvers, 2013), not only with respect to invited processes such as surveys and deliberative fora but in terms of all the diverse forms of public involvement that make up public issues relating to climate change. So our final point is to stress the importance of opening up to, acknowledging, and better accounting for the diverse ways in which publics are already engaging with and mobilising around such issues in 'uninvited' and multiple ways (cf. Wynne, 2007) - ranging from activism and public campaigns (e.g. Fish Fight), community flood groups, community beach surveying and co-management (e.g. the Marine Conservation Society), through to diverse responses and distributed innovations occurring at the household level and in wider society. The real challenge for science and policy institutions in the climate change domain is to understand, learn from and respond to these diverse public engagements, rather than seeing them as a problem, threat or something to be controlled. It is in these more humble terms that science and policy institutions have a better chance of mobilising change to address significant environmental problems, even on some of the more complex and distant marine climate change impacts dealt with in this paper.

\section{Acknowledgements}

The research reported on in this paper formed part of the CLAMER (Climate Change and European Marine Ecosystem Research) project funded under the EU's $7^{\text {th }}$ Framework Program (FP7-2009-1244132). We thank our collaborators Anna Dudek and Anabella Arquati at TNS-BMRB and assistance provided by our European-wide CLAMER partners. We also thank staff and students at the University of East Anglia and CEFAS for their involvement in translating survey responses, and Robert Bellamy, Helen Pallett, Jaap Rozema and Tina Wegg for assisting with the participatory workshop and/or coding the survey data. Of course, the study would not have been possible without the involvement of participants in the European survey and UK workshop, to whom we are very grateful. The paper was improved in response to comments from two anonymous reviewers, and comments from Mike Hulme on an earlier version of the manuscript. Any errors or omissions that remain are our own. 
[Pre-print - authors' accepted manuscript version. Please cite as the published version: Chilvers, J., Lorenzoni, I., Terry, G., Buckley, P., Pinnegar, J.K. \& Gelcich, S. (2014) 'Public engagement with marine climate change issues: (Re)framings, understandings and responses', Global Environmental Change 29: 165-179. Available at: http://dx.doi.org/10.1016/j.gloenvcha.2014.09.006]

\section{References}

Adger, N., Lorenzoni, I. and O'Brien, K. (2009) Adapting to Climate Change: Thresholds, Values, Governance. Cambridge: Cambridge University Press.

Bickerstaff, K., Simmons, P. and N. Pidgeon (2006). Public perceptions of risk, science and governance: main findings of a qualitative study of six risk cases. (Technical Report 06-03) Norwich: Centre for Environmental Risk.

Boykoff, M.T. \& Roberts, J.T. (2007) Media coverage of climate change: current trends, strengths, weaknesses. In UNDP (ed.) Human Development Report 2007/2008 - Fighting Climate Change: Human Solidarity in a Divided World. New York: United Nations Development Program.

Boykoff, M.T., Ghosh, A. and Venkateswaran, K. (2013) Media coverage on adaptation: competing visions of 'success' in the Indian context. In Moser, S.C. and Boykoff M.T. (eds.) Successful Adaptation to Climate Change: Linking Science and Practice in a Rapidly Changing World. London: Routledge, 237-252.

Brechin S.R. and Bhandari, M. (2014) Perceptions of climate change worldwide. Wiley Interdisciplinary Reviews: Climate Change, 2: 871-885.

Brody, S. D., Zahran, S., Vedlitz A. and Grover H. (2008) Examining the relationship between physical vulnerability and public perceptions of global climate change in the United States. Environment and Behavior 40(1), 72-95.

Brown, M. (2009) Science in Democracy: Expertise, Institutions, and Representation. MIT Press.

Bryman, A. (2004) Quantity and Quality in Social Science Research. New York: Routledge.

Bunce, M., Rosendo, S. and Brown, K. (2010) Perceptions of climate change, multiple stressors and livelihoods on marginal African coasts. Environment, Development and Sustainability, 12: 407-440.

Burgess, J., Limb, M. and Harrison, C. M. (1988) Exploring environmental values through the medium of small groups: theory and practice. Environment and Planning A 20(3), 309- 26. 
[Pre-print - authors' accepted manuscript version. Please cite as the published version: Chilvers, J., Lorenzoni, I., Terry, G., Buckley, P., Pinnegar, J.K. \& Gelcich, S. (2014) 'Public engagement with marine climate change issues: (Re)framings, understandings and responses', Global Environmental Change 29: 165-179. Available at: http://dx.doi.org/10.1016/j.gloenvcha.2014.09.006]

Burgess, J., Stirling, A., Clark, J., Davies, G., Eames, M., Staley, K. \& Williamson, S. (2007)

Deliberative mapping: a novel analytic-deliberative methodology to support contested science-policy decisions. Public Understanding of Science 16, 299-322.

Callon, M., Lascoumes, P. \& Barthe Y. (2009) Acting in an Uncertain World: An Essay on Technical Democracy, Cambridge, MA: MIT Press.

Capstick, S.B. and Pidgeon, N.F. (2014) Public perception of cold weather events as evidence for and against climate change. Climatic Change, 122(4):695-708.

Carlton, S.J. and Jacobson, S.K. (2013) Climate change and coastal environmental risk perceptions in Florida. Journal of Environmental Management, 130: 32-39.

Carolan, M.S. (2007) Introducing the concept of tactile space: Creating lasting social and environmental commitments. Geoforum 38(6), 1264-1275.

Carvalho, A. and Burgess, J. (2005) Cultural circuits of climate change in UK broadsheet newspapers, 1985-2003. Risk Analysis 25(6), 1457-1469.

Chambers, R. (1994) Participatory Rural Appraisal (PRA): Analysis of Experience. World Development 22, 1253-1263.

Cheung, W.W.L., Lam, V.W.Y., Sarmiento, J.L., Kearney, K., Watson, R., Zeller, D. and Pauly, D. (2010) Large-scale redistribution of maximum catch potential in the global ocean under climate change. Global Change Biol 16, 24-35.

Chilvers, J. (2008) Deliberating competence: theoretical and practitioner perspectives on effective participatory appraisal practice. Science, Technology and Human Values 33(2), 155-185.

Chilvers, J. and Burgess, J. (2008) Power relations: the politics of risk and procedure in nuclear waste governance. Environment and Planning A 40, 1881-1900.

Chilvers, J. and Evans, J (2009) Understanding networks at the science-policy interface. Geoforum $40,355-362$. 
[Pre-print - authors' accepted manuscript version. Please cite as the published version: Chilvers, J., Lorenzoni, I., Terry, G., Buckley, P., Pinnegar, J.K. \& Gelcich, S. (2014) 'Public engagement with marine climate change issues: (Re)framings, understandings and responses', Global Environmental Change 29: 165-179. Available at: http://dx.doi.org/10.1016/j.gloenvcha.2014.09.006]

Chilvers, J. (2013) Reflexive engagement? Actors, learning, and reflexivity in public dialogue on science and technology. Science Communication 35: 283-310.

Combest-Friedman, C., Christie, P. and Miles, E. (2012) Household perceptions of coastal hazards and climate change in the Central Philippines. Journal of Environmental Management, 112:137-148.

Corner, A., Parkhill, K., Pidgeon, N. \& Vaughan, N.E. (2013) Messing with nature? Exploring public perceptions of geoengineering in the UK, Global Environmental Change 23: 938-947.

Corner, A., Markowitz, E. and Pidgeon, N. (2014) Public engagement with climate change: the role of human values. Wiley Interdisciplinary Reviews: Climate Change, 5: 411-422.

DEFRA (2012) UK Climate Change Risk Assessment. Floods and Coastal Erosion Summary Report. London: The Stationery Office.

Devine-Wright, P. (2011) Enhancing local distinctiveness fosters public acceptance of tidal energy: A UK case study. Energy Policy 39(1), 83-93.

Devine-Wright. P. (2013) Think global, act local? The relevance of place attachments and place identities in a climate changed world. Global Environmental Change, 23: 61-69.

Devine-Wright, P. and Howes, Y. (2010) Disruption to place attachment and the protection of restorative environments: a wind energy case study. J. Environmental Psychology, 30:271-280.

Dolan, A.H. and Walker, I.J. (2006) Understanding vulnerability of coastal communities to climate change related risks. Journal of Coastal Research 3, 1316-1323.

European Commission and European Parliament (2009). Special Eurobarometer 313: Europeans' attitudes towards climate change, http://ec.europa.eu/public_opinion/archives/ebs/ebs_313_en.pdf

Felt, U. and Wynne, B. (2007) Taking European Knowledge Seriously. Report of the Expert Group on Science and Governance to the Science, Economy and Society Directorate. Brussels: DirectorateGeneral for Research, European Commission. 
[Pre-print - authors' accepted manuscript version. Please cite as the published version: Chilvers, J., Lorenzoni, I., Terry, G., Buckley, P., Pinnegar, J.K. \& Gelcich, S. (2014) 'Public engagement with marine climate change issues: (Re)framings, understandings and responses', Global Environmental Change 29: 165-179. Available at: http://dx.doi.org/10.1016/j.gloenvcha.2014.09.006]

Fletcher, S., Potts, J.S., Heeps, C. and Pike, K. (2009) Public awareness of marine environmental issues in the UK. Marine Policy 33(2), 370-375.

Gee, K. (2010) Offshore wind power development as affected by seascape values on the German North Sea Coast. Land Use Policy, 27: 185-194.

Gelcich, S., Buckley P., Pinnegar J.K., Chilvers J., Lorenzoni I., Terry G., Guerrero M., Castilla J.C., Valdebenito, A., and Duarte C.M., (in press) Public awareness, concerns, and priorities about anthropogenic impacts on marine environments, Proc Natl Acad Sci USA, www.pnas.org/cgi/doi/10.1073/pnas.1417344111

Greenpeace (2010) Emergency Oceans Rescue Plan: Implementing the Marine Reserves Roadmap to Recovery, Amsterdam: Greenpeace International.

Grothmann, T. and Patt, A. (2005) Adaptive capacity and human cognition: The process of individual adaptation to climate change. Global Environmental Change-Human and Policy Dimensions 15(3), 199-213.

Haggett, C. (2008) Over the sea and far away? A consideration of the planning, politics and public perception of offshore wind farms. Journal of Environmental Policy 10(3), 289-306.

Harries, T. and Penning-Rowsell, E. (2011) Victim pressure, institutional inertia and climate change adaptation: The case of flood risk. Global Environmental Change 21, 188-197.

Harvatt, J., Petts, J. and Chilvers, J. (2011). Understanding householder responses to natural hazards: flooding and sea level rise comparisons. Journal of Risk Research 14(1), 63-83.

Heip, C. (2011) Climate change impacts on marine ecosystems in Europe. In Mees, J., Seys, J., Watmough, T. and Rappé, K. (Eds) Proceedings 'Living with a warming ocean: European research and public perception of climate change impacts in the marine environment', International CLAMER conference, Brussels, 14-15 September 2011. VLIZ Special Publication 53. Oostende, Belgium: Flanders Marine Institute (VLIZ), p.11-12. 
[Pre-print - authors' accepted manuscript version. Please cite as the published version: Chilvers, J., Lorenzoni, I., Terry, G., Buckley, P., Pinnegar, J.K. \& Gelcich, S. (2014) 'Public engagement with marine climate change issues: (Re)framings, understandings and responses', Global Environmental Change 29: 165-179. Available at: http://dx.doi.org/10.1016/j.gloenvcha.2014.09.006]

Heip, C., Grehan, A., She, J., Barange, M., Tréguer, P., Wassmann, P., Weaver, P., Warren, R., Danovaro, R., Papathanassiou, E., Yu, R., Gehlen, M., Oguz, T., Philippart, C., Meysman, F., de Baar, H., Tsimplis, M., Cooper, A., Pedersen, L. T., Von Storch, H., Boyd, P., van Beusekom, J., Ludwig, W., Janssen, F., and de Haas, H. (2011) Climate Change and Marine Ecosystem Research: Synthesis of European Research on the Effects of Climate Change on Marine Environments. Marine Board Special Report. Ostend, Belgium: Marine Board.

Hinkel J., Nicholls R., Vafeidis A., Tol R. and Avagianou, T. (2010) Assessing risk of and adaptation to sea level rise in the European Union: an application of DIVA. Mitigation and Adaptation Strategies for Global Change 15(7), 703-719.

HM Government (2013) The National Adaptation Programme, London: The Stationery Office.

Howard, C. and Parsons E.C.M. (2006) Attitudes of Scottish city inhabitants to cetacean conservation. Biodiversity and Conservation 15, 4335-4356.

Hyne, S., Norton, D. and Corless, R. (2014) Investigating societal attitudes towards the marine environment of Ireland. Marine Policy, 47, 57-65.

IPCC (2007a) Climate change 2007: The Physical Science Basis. Contribution of Working Group I to the Fourth Assessment Report of the Intergovernmental Panel on Climate Change. Cambridge: Cambridge University Press.

IPCC (2007b) Contribution of Working Group II to the Fourth Assessment Report of the Intergovernmental Panel on Climate Change. M.L. Parry, O.F. Canziani, J.P. Palutikof, P.J. van der Linden and C.E. Hanson (eds) Cambridge: Cambridge University Press.

IPCC (2013) Climate Change 2013: The Physical Science Basis. Working Group I Contribution to the Fifth Assessment Report of the Intergovernmental Panel on Climate Change. Stocker, T.F., Qin, D., Plattner, G-K., Tignor, M.M.B, Allen, S.K., Boschung, J., Nauels, A., Xia, Y., Bex, V. and Midgley, P.M. (eds) Cambridge: Cambridge University Press.

IPCC (2014) Climate Change 2014: Impacts, Adaptation and Vulnerability. IPCC WG2 AR5 Summary for policymakers. Cambridge: Cambridge University Press. 
[Pre-print - authors' accepted manuscript version. Please cite as the published version: Chilvers, J., Lorenzoni, I., Terry, G., Buckley, P., Pinnegar, J.K. \& Gelcich, S. (2014) 'Public engagement with marine climate change issues: (Re)framings, understandings and responses', Global Environmental Change 29: 165-179. Available at: http://dx.doi.org/10.1016/j.gloenvcha.2014.09.006]

Ipsos MORI Research Institute (2013) PREPARE - Climate risk acceptability - Findings from a series of deliberative workshops and online survey. Part of the PREPARE Programme of research on preparedness, adaptation and risk, Final Report for project ERG1211 by Ricardo-AEA for Defra. Ipsos-Mori and AEA.

Irwin, A. (1995) Citizen Science. London: Routledge.

Irwin, A. and B. Wynne (1996) Misunderstanding science? The public reconstruction of science and technology. Cambridge, Cambridge University Press.

Jick, T.D. (1979) Mixing Qualitative and Quantitative Methods: Triangulation in Action. Administrative Science Quarterly, 24(4): 602-611.

Kasemir, B., Jager, J., Jaeger, C.C., Gardner, M.T. (Eds.) Public Participation in Sustainability Science: A handbook. Cambridge University Press, Cambridge.

Latour, B. (2004) Politics of Nature: How to Bring the Sciences into Democracy. Cambridge MA: Harvard University Press.

Le Quéré, C., Raupach, M.R., Canadell, J.G., Marland, G. et al (2009) Trends in the sources and sinks of carbon dioxide, Nature Geoscience 2, $831-836$.

Linnekamp, F., Koedam, A. and Baud, I.S.A. (2011) Household vulnerability to climate change: examining perceptions of households of flood risks in Georgetown and Paramaribo. Habitat International, 35:447-456.

Lonsdale, K.G., Downing, T.E., Nicholls R.J., Parker, D., Vafeidis, A.T., Dawson, R. and Hall, J. (2008) Plausible responses to the threat of rapid sea level rise in the Thames Estuary. Climatic Change 91(1-2), 145-169.

Lorenzoni, I., Leiserowitz A., De Franca Doria, M., Poortinga W. and Pidgeon N. (2006) Crossnational comparisons of image associations with "global warming" and "climate change" among laypeople in the United States of America and Great Britain. Journal of Risk Research 9(3), 265-281. 
[Pre-print - authors' accepted manuscript version. Please cite as the published version: Chilvers, J., Lorenzoni, I., Terry, G., Buckley, P., Pinnegar, J.K. \& Gelcich, S. (2014) 'Public engagement with marine climate change issues: (Re)framings, understandings and responses', Global Environmental Change 29: 165-179. Available at: http://dx.doi.org/10.1016/j.gloenvcha.2014.09.006]

Lorenzoni, I., Nicholson-Cole, S. and Whitmarsh, L. (2007) Barriers perceived to engaging with climate change among the UK public and their policy implications. Global Environmental Change Human and Policy Dimensions 17(3-4), 445-459.

Malka, A., Krosnick , J.A. and Langer, G. (2009) The association of knowledge with concern about global warming: Trusted information sources shape public thinking. Risk Analysis 29(5), 633-647.

Marres, N. (2007) The issues deserve more credit: pragmatist contributions to the study of public involvement in controversy. Social Studies of Science 37: 759-780.

McLachlan, C. (2009) 'You don't do a chemistry experiment in your best china': symbolic interpretations of place and technology in a wave energy case. Energy Policy, 27(12):5342-5350.

Mee, L. D., Jefferson R.L., Laffoley D.d'A. and Elliott M. (2008) How good is good? Human values and Europe's proposed Marine Strategy Directive. Marine Pollution Bulletin 56, 187-204.

Moser, S. (2013) Navigating the political and emotional terrain of adaptation: community engagement when climate change comes home. In Moser, S. \& Boykoff, M.T (eds.) Successful Adaptation to Climate Change: Linking Science and Policy in a Rapidly Changing World. London: Routledge, p.289-305.

Moser, S. (2014) Communicating adaptation to climate change: the art and science of public engagement when climate change comes home. Wiley Interdisciplinary Reviews: Climate Change, 5: 337-358.

Myatt-Bell, L. B., Scrimshaw, M. D., Lester, J.N. and Potts, J.S. (2002) Public perception of managed realignment: Brancaster West Marsh, North Norfolk, UK. Marine Policy 26(1): 45-57.

Nisbet, M.C. (2009) Communicating climate change: Why frames matter for public engagement. Environment 2: 1-26.

O’Neill, S. J. and M. Hulme (2009) An iconic approach for representing climate change. Global Environmental Change-Human and Policy Dimensions 19(4), 402-410. 
[Pre-print - authors' accepted manuscript version. Please cite as the published version: Chilvers, J., Lorenzoni, I., Terry, G., Buckley, P., Pinnegar, J.K. \& Gelcich, S. (2014) 'Public engagement with marine climate change issues: (Re)framings, understandings and responses', Global Environmental Change 29: 165-179. Available at: http://dx.doi.org/10.1016/j.gloenvcha.2014.09.006]

O'Neill, S. and S. Nicholson-Cole (2009) 'Fear won't do it': Promoting positive engagement with climate change through visual and iconic representations. Science Communication 30(3), 355-379.

Paeth, H. and C. Otto (2009) The population's view on climate change and mitigation inferences for media and policy. Advanced Science Letters 2(3), 310-318.

Peters, E. and Slovic, P. (1996) The role of affect and worldviews as orienting dispositions in the perception and acceptance of nuclear power, Journal of Applied Social Psychology, 26,1427-1453.

Philippart, C.J.M., Anadon, R., Danovaro, R., Dippner, J.W., Drinkwater, K.F., Hawkins, S.J., Oguz, T., O'Sullivan, G. and Reid P.C. (2011) Impacts of climate change on European marine ecosystems: Observations, expectations and indicators. J. Exp. Mar. Biol. Ecol. 400, 52-69.

Pielke Jr, R., Prins, G., Rayner, S. and Sarewitz, D. (2007) Lifting the taboo on adaptation. Nature, 445, 597-598.

Poortinga, W. and Pidgeon, N.F. (2003) Exploring the dimensionality of trust in risk regulation. Risk Analysis 23(5), 961-972.

Quinn, T. and Adger, W.N. (2011) Climate change when you are getting on in life. Commentary. Environment and Planning A, 43:2257-2260.

Reynolds, T.W., Bostrom A., Read, D. and Granger, M.M. (2010) Now what do people know about global climate change? Survey studies of educated laypeople. Risk Analysis 30(10), 1520-1538.

Richardson, A.J. and Poloczanska, E.S. (2008) Under-resourced, under threat. Science 320, 1294-5.

Ritchie, H. and Ellis, G. (2010) A system that works for the sea'? Exploring stakeholder engagement in marine spatial planning. Journal of Environmental Planning and Management 53(6), 701-723.

Shackley, S., McLachlan, C., and Gough, C. (2005) The public perception of carbon dioxide capture and storage in the UK: Results from focus groups and a survey. Climate Policy 4(4), 377-398. 
[Pre-print - authors' accepted manuscript version. Please cite as the published version: Chilvers, J., Lorenzoni, I., Terry, G., Buckley, P., Pinnegar, J.K. \& Gelcich, S. (2014) 'Public engagement with marine climate change issues: (Re)framings, understandings and responses', Global Environmental Change 29: 165-179. Available at: http://dx.doi.org/10.1016/j.gloenvcha.2014.09.006]

Sherry-Brennan, F., Devine-Wright, H. and Devine-Wright, P. (2010) Public understanding of hydrogen energy: a theoretical approach. Energy Policy, 38(10):5311-5319.

Shove, E. (1998) Gaps, barriers and conceptual chasms: theories of technology transfer and energy in buildings. Energy Policy, 28(15), 1105-1112.

Shove, E. (2010) Beyond the ABC: climate change policy and theories of social change. Environment and Planning 42(6), 1273-1285.

Shwom, R., Bidwell, D., Dan, A. and Dietz, T. (2010) Understanding US public support for domestic climate change policies. Global Environmental Change - Human and Policy Dimensions 20(3), 472482.

Shwom R. and Lorenzen, J.A. (2012) Changing household consumption to address climate change: social scientific insights and challenges. Wiley Interdisciplinary Reviews: Climate Change, 3: 379395.

Silverman, D. (1993) Interpreting Qualitiative Data: Methods for Analysing Talk, Text and Interaction, London, Sage.

Spence, A., Venables, D., Pidgeon, N., Poortinga, W. and Demski, C. (2010a) Public Perceptions of Climate Change and Energy Futures in Britain: Summary Findings of a Survey Conducted in January-March 2010. Technical Report (Understanding Risk Working Paper 10-01). Cardiff: School of Psychology.

Spence, A., Poortinga, W., Pidgeon, N. and Lorenzoni, I. (2010b) Public perceptions of energy choices: the Influence of beliefs about climate change and the environment. Energy \& Environment 21(5): 385-407.

Spence, A., Poortinga, W., Butler, C., and Pidgeon, N. (2011) Perceptions of climate change and willingness to save energy related to flood experience. Nature Climate Change, 1, 46-49.

Spence, A., Poortinga, W. and Pidgeon, N. (2012) The psychological distance of climate change. Risk Analysis, 32(6):957-972. 
[Pre-print - authors' accepted manuscript version. Please cite as the published version: Chilvers, J., Lorenzoni, I., Terry, G., Buckley, P., Pinnegar, J.K. \& Gelcich, S. (2014) 'Public engagement with marine climate change issues: (Re)framings, understandings and responses', Global Environmental Change 29: 165-179. Available at: http://dx.doi.org/10.1016/j.gloenvcha.2014.09.006]

Sundblad, E.L., Biel A. and Garling, T. (2007) Cognitive and affective risk judgements related to climate change. Journal of Environmental Psychology 27(2), 97-106.

Szalay, L. B. and Deese, J. (1978) Subjective Meaning and Culture: An Assessment Through Word Associations. Hillsdale, NJ: Lawrence Erlbaum Associates.

Tol, R.S. (2007) The double trade-off between adaptation and mitigation for sea-level rise: an application of FUND. Mitigation and Adaptation Strategies for Global Change 12(5), 741-753.

Tompkins, E.L., Few, R. and Brown, K. (2008) Scenario-based stakeholder engagement: Incorporating stakeholders preferences into coastal planning for climate change. Journal of Environmental Management. 88: 1580-1592.

Van Koningsveld, M., Mulder, J.P.M., Stive, M.J.F., VanDerValk L. and VanDerWeck A.W. (2008) Living with sea-level rise and climate change: A case study of the Netherlands. Journal of Coastal Research 24(2), 367-379.

Verweij, M., Douglas, M., Ellis, R., Engel, C., Hendriks, F., Lohmann, S., Ney, S., Rayner, S. and Thompson, M. (2006) Clumsy solutions for a complex world: The case of climate change. Public Administration 84(4), 817-843.

Webler, T., Kastenholz, H. and Renn, O. (1995) Public participation in impact assessment: a social learning perspective. Environmental Impact Assessment Review 15, 443-463.

Whitmarsh, L. (2008) Are flood victims more concerned about climate change than other people? The role of direct experience in risk perception and behavioural response. Journal of Risk Research 11(3), 351-374.

Whitmarsh, L. (2009) Behavioural responses to climate change: A symmetry of intentions and impacts. Journal of Environmental Psychology 29(1), 13-23.

Whitmarsh, L. (2011) Scepticism and uncertainty about climate change: Dimensions, determinants and change over time. Global Environmental Change-Human and Policy Dimensions 21(2), 690-700. 
[Pre-print - authors' accepted manuscript version. Please cite as the published version: Chilvers, J., Lorenzoni, I., Terry, G., Buckley, P., Pinnegar, J.K. \& Gelcich, S. (2014) 'Public engagement with marine climate change issues: (Re)framings, understandings and responses', Global Environmental Change 29: 165-179. Available at: http://dx.doi.org/10.1016/j.gloenvcha.2014.09.006]

Wolf, J. and Moser, S.C. (2011) Individual understandings, perceptions, and engagement with climate change: insights from in-depth studies across the world. Wiley Interdisciplinary Reviews: Climate

Change 2(4), 547-569.

Wynne, B. (1991) Knowledges in Context. Science Technology and Human Values 19, 1-17.

Wynne, B. (1993). Public uptake of science: A case for institutional reflexivity. Public Understanding of Science 2, 321-337.

Wynne, B. (2007) Public participation in science and technology: performing and obscuring a political-conceptual category mistake. East Asian Science, Technology and Society: An International Journal 1, 99-110.

Yohe, G. and Tol R.S.J. (2002) Indicators for social and economic coping capacity: moving toward a working definition of adaptive capacity. Global Environmental Change 12(1), 25-40.

Zsamboky, M., Fernández-Bilbao A., Smith, D., Knight, J. and Allan, J. (2011) Impacts of climate change on disadvantaged UK coastal communities. York, Joseph Rowntree Foundation. 